Article

\title{
The Application of Ground-Based and Satellite Remote Sensing for Estimation of Bio-Physiological Parameters of Wheat Grown Under Different Water Regimes
}

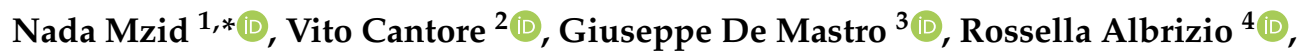 \\ Mohamed Houssemeddine Sellami ${ }^{4}$ (D) and Mladen Todorovic ${ }^{1, *(D)}$ \\ 1 CIHEAM-Mediterranean Agronomic Institute of Bari, 70010 Valenzano, Bari, Italy \\ 2 Institute of Sciences of Food Production, National Research Council (CNR-ISPA), Via Amendola, 122/O, \\ 70125 Bari, Italy; vito.cantore@ispa.cnr.it \\ 3 Department of Agricultural and Environmental Science, University of Bari “A. Moro" Via Amendola, 165/A, \\ 70126 Bari, Italy; giuseppe.demastro@uniba.it \\ 4 Institute for Mediterranean Agricultural and Forestry Systems, National Research Council, Via Patacca, 85, \\ 80056 Ercolano Naples, Italy; rossella.albrizio@cnr.it (R.A.); mohamed.sellami@isafom.cnr.it (M.H.S.) \\ * Correspondence: nada.mzid@unitus.it (N.M.); mladen@iamb.it (M.T.)
}

Received: 20 May 2020; Accepted: 20 July 2020; Published: 24 July 2020

check for updates

\begin{abstract}
Remote sensing technologies have been widely studied for the estimation of crop biometric and physiological parameters. The number of sensors and data acquisition methods have been increasing, and their evaluation is becoming a necessity. The aim of this study was to assess the performance of two remote sensing data for describing the variations of biometric and physiological parameters of durum wheat grown under different water regimes (rainfed, 50\% and $100 \%$ of irrigation requirements). The experimentation was carried out in Policoro (Southern Italy) for two growing seasons. The Landsat 8 and Sentinel-2 images and radiometric ground-based data were acquired regularly during the growing season with plant biometric (leaf area index and dry aboveground biomass) and physiological (stomatal conductance, net assimilation, and transpiration rate) parameters. Water deficit index was closely related to plant water status and crop physiological parameters. The enhanced vegetation index showed slightly better performance than the normalized difference vegetation index when plotted against the leaf area index with $R^{2}=0.73$. The overall results indicated that the ground-based vegetation indices were in good agreement with the satellite-based indices. The main constraint for effective application of satellite-based indices remains the presence of clouds during the acquisition time, which is particularly relevant for winter-spring crops. Therefore, the integration of remote sensing and field data might be needed to optimize plant response under specific growing conditions and to enhance agricultural production.
\end{abstract}

Keywords: vegetation indices; water deficit index; enhanced vegetation index; irrigation

\section{Introduction}

In the last decade, the development of earth observation technology, especially satellite remote sensing, has made massive remotely sensed data available for research and various applications $[1,2]$. Agricultural remote sensing is a highly specialized field to generate images and spectral data in volume and complexity to drive decisions for agricultural development. Agricultural systems can be made resource-efficient by integrating tools, technologies, and information management systems that come under Precision Agriculture (PA). Such a concept implies observation, measurement, and response 
to inter- and intra-field variability in crops employing information technology [3]. Remote sensing is the cornerstone of modern precision agriculture [4]. It aims to optimize farm inputs, to improve efficiency of water/nutrient application, and to realize site-specific crop field management strategies that account for within-field variability of soil, early detection of plant abiotic/biotic stresses, and the effects of applied treatments. This is done by focusing on the best management practice at the right rate and time and in the right place [5].

Remote sensing technology has been developed for earth observation from different sensors and platforms. Sensors are mainly used for imaging and non-imaging broadband multispectral or narrow-band hyper-spectral data acquisition. Platforms are space-borne for satellite-based sensors, airborne for sensors on manned and unmanned airplanes, and ground-based for field and laboratory sensors [5].

Remote sensing-based indices are an effective tool for water/nutrient requirement monitoring [6], crop growth and yield investigation through various phenological stages [7] and vegetation health status, and monitoring of abiotic stresses. Vegetation indices (VIs) have been developed by combining the remote sensing data and the reflectance of monitored surfaces within different wavebands, mainly visible and Near Infrared (NIR). VIs provide consistent spatial and temporal comparisons of global vegetation conditions [8].

The indices frequently used in the agricultural sector are Normalized Difference Vegetation Index (NDVI) [9-13], Soil Adjusted Vegetation Index (SAVI) [14-17], and Enhanced Vegetation Index (EVI) $[18,19]$.

Normalized Difference Vegetation Index (NDVI) is one of the most common spectral indices used in the crop canopy studies. It is defined in terms of the Near Infrared (NIR) and Red (R) satellite bands as $(\mathrm{NIR}-\mathrm{R}) /(\mathrm{NIR}+\mathrm{R})$. Satellite-derived NDVI time-series data characterize the annual greenness changes on land surfaces, the radiance reflected in the $\mathrm{R}$ band related to the amount of chlorophyll, and the radiance in the NIR band related to the density of green leaves [20]. The index is an important data source for many applications, such as the estimation of vegetation photosynthetic activity [21], detection of vegetation phenology [22,23], and classification of land cover [24]. NDVI has also been used with land-surface models for quantitative prediction of vegetation health [25]. Despite the usefulness of NDVI data in vegetation studies, its application has been limited mainly to the issue of interaction of soil reflectance with overlying vegetation. To overcome this limitation, the alternatives to NDVI such as the Soil Adjusted Vegetation Index (SAVI) [26], Generalized SAVI (GESAVI) [27], and Enhanced Vegetation Index (EVI) [28] have been yielded. Huete [26] proposed using a soil-adjustment factor "L" to account for first-order soil background variations and obtained a soil-adjusted vegetation index (SAVI). Soil-adjusted indices such as the Transformed Soil-Adjusted Vegetation Index (TSAVI) [29], the Modified Soil-Adjusted Vegetation Index (MSAVI) [30], the Optimized Soil-Adjusted Vegetation Index (OSAVI) [31], and the Generalized Soil-Adjusted Vegetation Index (GESAVI) [27] have attempted to minimize brightness-related soil effects. The EVI was proposed based on a feedback-based approach that incorporates both background adjustment and atmospheric resistance concepts into the NDVI [32]. Thus, the EVI has been considered a modified NDVI with improved sensitivity to high biomass regions and improved vegetation-monitoring capability through decoupling of the canopy background signal and a reduction in atmospheric influences [33].

Along with the spectral indices, thermal remote sensing indices are very useful for crop stress monitoring. For this purpose, surface temperature is considered a rapid response variable that can indicate crop stress prior to their visual symptoms. By measuring estimates of surface temperature, Thermal Remote Sensing (TRS) has been indicated as a promising tool for precision agriculture [34]. Thus, a series of satellite and airborne thermal sensors have been developed and used directly or indirectly for many agricultural applications. Surface temperature detected by thermal sensors is found to be a rapid response variable for crop and soil monitoring in the agricultural sector [35,36], including estimating soil moisture and crop water stress for irrigation scheduling [3,37,38], determining disease and pathogen infected crops [39], mapping soil texture, estimating residue cover, locating tiles in fields, monitoring crop maturity 
for harvesting [40], and mapping crop yield [41,42]. Crop water demand for growth and cooling purposes is directly related to leaf or canopy temperature and soil moisture [43]. Thermal remote sensing has been suggested as a potential tool to determine the irrigation needs and crop's water status in a variety of studies [44-46]. These studies assume that soil surface is completely covered by vegetation and not viewed by sensors, so that canopy temperature is obtained by thermal infrared measurements. However, soil background causes a false indication of water stress in the early stage of crop growth or in the case of low plant population because dry soil temperature is often higher than air temperature. To overcome this limitation, Moran et al. [47] developed the Water Deficit Index (WDI) to take into account vegetation cover using the difference between canopy temperature $\left(\mathrm{T}_{\mathrm{c}}\right)$ and air temperature $\left(\mathrm{T}_{\mathrm{A}}\right)$ against an NDVI scatter plot. This "trapezoid method" appears to have potential for evaluating the evapotranspiration rate and relative field water deficit for both full-cover and partially vegetated sites.

It is frequently desirable to compare the same vegetation indices over time and space using data from different sensors. Verhoelst et al. [48] reported that the comparisons with ground-based correlative measurements constitute a key component in the validation of satellite data on atmospheric composition. Satellite remote sensing along with ground-based remote sensing offer immense potentialities and advantages in performing useful geospatial operation and functionalities addressing various geo-disciplinary problems [49]. Based on Zhang [50], remote sensing data fusion, as one of the most commonly used techniques, aims to integrate the information acquired with different spatial and spectral resolutions from sensors mounted on satellites, aircraft, and ground platforms to produce fused data that contain more detailed information than each of the sources. Due to the development of multi-view and multi-resolution earth observation systems, data fusion of satellite, aerial, and close-range images is necessary for precision agriculture and environmental monitoring application. Care must be exercised in making such comparisons because the band-response functions for each instrument are different.

Despite the successful application of high spatial and spectral resolution sensors in agricultural studies, there are challenges related to high acquisition costs, small area coverage, and limited availability [51]. The abovementioned limitations have therefore seen a shift toward the use of free and readily available broadband multispectral sensors with a large swath width such as Landsat and Sentinel datasets. The free availability of Landsat 8 Operational Land Imager (OLI) and Sentinel-2A Multi Spectral Instrument (MSI) data significantly advances the virtual constellation paradigm for mid-resolution land imaging [52,53]. The spatial resolution of $10 \mathrm{~m}$ in four visible and NIR bands lies directly between the Landsat 8 multispectral bands at $30 \mathrm{~m}$.

In this study, we hypothesize that there is a correspondence between satellite imagery and ground-based vegetation indices. In order to verify this hypothesis, the objectives of the study are as follows:

- to assess the relationships between remote sensing vegetative indices, and biometric and physiological parameters of wheat grown under different water regimes;

- to compare the ground-based remote sensing indices with the same indices derived from satellite imagery; and

- to evaluate the estimation of the Vegetation Index/Temperature (VIT) trapezoid from the ground-based and satellite temperature data.

\section{Materials and Methods}

\subsection{Experimental Site and Design}

The experimental study has been conducted at the experimental farm "E. Pantanelli" of Bari University "Aldo Moro", located in Policoro, Southern Italy (MT). The climate is subhumid Mediterranean according to the De Martonne climate classification [54] with an annual rainfall of $600 \mathrm{~mm}$, while the average annual temperature ranges around $16-17^{\circ} \mathrm{C}$. The soil is defined as fine, mixed, sub-active, and thermic Chromic Haploxererts [55]. 
Durum wheat (Triticum durum Desf.) was cultivated in two growing seasons (February-June 2015 and December 2015-July 2016) in nine experimental plots, each covering a surface of 0.185 ha $\left(43 \times 43 \mathrm{~m}^{2}\right)$. Three water regimes were adopted, i.e., rainfed $(\mathrm{RF})$, deficit $\left(\mathrm{I}_{50}\right)$, and full $\left(\mathrm{I}_{100}\right)$ irrigation; where $\mathrm{I}_{50}$ and $\mathrm{I}_{100}$ corresponded to $50 \%$ and $100 \%$ of irrigation requirements, respectively. Each treatment was replicated three times.

The climatic data over the study period were recorded by an agrometeorological station located a few hundred meters away from the wheat field. Air temperature was increasing from sowing to harvesting in both years. In particular, in the first cropping season, the minimum daily temperature $\left(\mathrm{T}_{\min }\right.$ ) ranged between 2.3 (March 10 and 17) and $18.5^{\circ} \mathrm{C}$ (June 4), while the maximum temperature $\left(\mathrm{T}_{\max }\right.$ ) was between 8.5 (March 10) and $32.1^{\circ} \mathrm{C}$ (June 10 and 12). In the second cropping season, $\mathrm{T}_{\min }$ ranged between $-1.0^{\circ} \mathrm{C}$ (December 26) and $15.2^{\circ} \mathrm{C}$ (May 14), while $\mathrm{T}_{\max }$ was between $5.8^{\circ} \mathrm{C}$ (January 27) and $28.8^{\circ} \mathrm{C}$ (May 22). Total precipitation during the crop growing cycle was 355 and $264 \mathrm{~mm}$ in 2015 and 2016, respectively. The cumulative reference evapotranspiration values during the crop cycle, calculated by the Food and Agriculture Organization (FAO) Penman-Monteith equation [56], were 504 and $590 \mathrm{~mm}$ in 2015 and 2016, respectively. Crop water balance and irrigation scheduling were managed using an Excel-based model [57] that estimates crop evapotranspiration and irrigation water requirements through the standard procedure proposed by FAO [56].

In both years, irrigation was applied three times, starting at flowering, with the total amount of $\mathrm{I}_{100}$ treatments corresponding to 1050 and $960 \mathrm{~m}^{3} /$ ha in 2015 and 2016, respectively. Half of these volumes was applied in $\mathrm{I}_{50}$ treatments.

\subsection{Ground-Based Remote Sensing Measurements}

\subsubsection{Canopy Reflectance and Vegetation Indices Calculation}

A high spectral resolution ASD FieldSpec Hand-Held 2 spectro-radiometer (Analytical Spectral Devices Inc, Boulder, CO, USA) was used to measure in situ canopy spectral reflectance. The instrument recorded reflectance between 325 and $1075 \mathrm{~nm}$, with an accuracy of $\pm 1 \mathrm{~nm}$ and a resolution of $<3 \mathrm{~nm}$ at $700 \mathrm{~nm}$. The readings were conducted around noon time (11:00 to 13:00) in all wheat plots. The sensor, with a field of view $25^{\circ}$, was placed approximately $1.2 \mathrm{~m}$ above durum wheat canopy (the height of the wheat at maturity stage was $89 \pm 2 \mathrm{~cm}$ ). Two replicates of spectral measurements were obtained in each plot. Measurements were taken under clear sky conditions, once a week from the beginning of the experimentation. Averages by treatment were calculated to serve after in the elaboration of vegetation indices. Appropriate spectral bands (visible and near infrared) were selected from the reflectance measurements, using the central value of each Landsat 8 and Sentinel 2 waveband, to compute specific VIs (as the Sentinel 2 spatial resolution of $10 \mathrm{~m}$ lies directly within the Landsat 8 multispectral bands at $30 \mathrm{~m})$.

\subsubsection{Canopy Temperature and WDI}

A portable thermal imaging camera (FLIR B335, FLIR Systems, Inc., Wilsonville, OR, USA) was used for the measurement of wheat canopy temperature. The handheld thermal imager range is $7.5-1.3 \mu \mathrm{m}$, allowing accurate temperature measurement with an infrared resolution of $320 \times 240$ pixels and lens with an angular field of view of $25^{\circ}(\mathrm{H}) \times 19^{\circ}(\mathrm{V})$. Imagery was taken across the experimental field on clear sky days' conditions at solar noon, once a week from the beginning of the experimentation. Image acquisition was preceded by taking the image at $1 \mathrm{~m}$ above the wheat canopy level. Thermal images of three water treatments were individually recorded twice by plot. Digital imageries were analyzed with ThermaCam Researcher Professional software.

Starting from the collected data, the theoretical Vegetation Index/Temperature (VIT) trapezoid approach, developed by Moran et al. [48], was used. The vertices of the trapezoid (Figure 1) constitute four extreme states of vegetation cover and water status. 


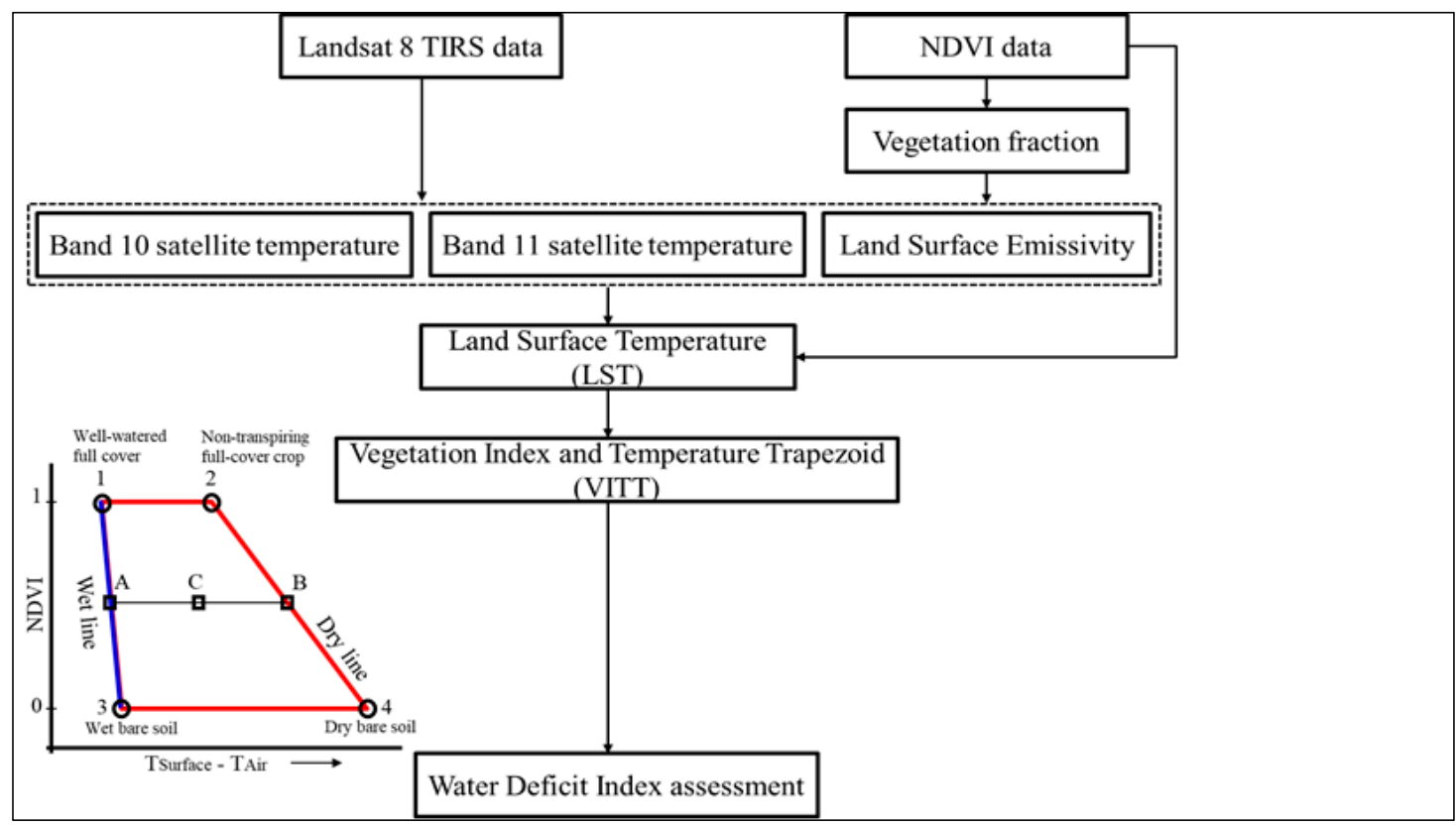

Figure 1. Flowchart of the methodology adopted for the estimation of land surface temperature and Water Deficit Index (WDI).

Hence, WDI was estimated as follows:

$$
\mathrm{WDI}=\frac{\left[\left(\mathrm{T}_{\mathrm{S}}-\mathrm{T}_{\mathrm{A}}\right)_{\mathrm{r}}-\left(\mathrm{T}_{\mathrm{S}}-\mathrm{T}_{\mathrm{A}}\right)_{\min }\right]}{\left[\left(\mathrm{T}_{\mathrm{S}}-\mathrm{T}_{\mathrm{A}}\right)_{\max }-\left(\mathrm{T}_{\mathrm{S}}-\mathrm{T}_{\mathrm{A}}\right)_{\min }\right]}
$$

where $\mathrm{T}_{\mathrm{S}}$ is the surface temperature $\left({ }^{\circ} \mathrm{C}\right) ; \mathrm{T}_{\mathrm{A}}$ is the air temperature $\left({ }^{\circ} \mathrm{C}\right)$; and $\mathrm{r}$, min, and max referred to the measured, minimum, and maximum values.

$\left(\mathrm{T}_{\mathrm{S}}-\mathrm{T}_{\mathrm{A}}\right)_{\text {min }}$ and $\left(\mathrm{T}_{\mathrm{S}}-\mathrm{T}_{\mathrm{A}}\right)_{\max }$ represented the wet and dry references, respectively, of WDI. These temperature references depend on vegetation indices (NDVI and/or SAVI). For each vertex of trapezoid, the $\left(\mathrm{T}_{\mathrm{S}}-\mathrm{T}_{\mathrm{A}}\right)_{\mathrm{i}}$ value (the subscript " $\mathrm{i}$ " referred to vertices 1 to 4 ) was based on the physical-based energy balance equations and can be computed for well-watered dense vegetation as follows:

$$
\left(\mathrm{T}_{\mathrm{s}}-\mathrm{T}_{\mathrm{A}}\right)_{1}=\frac{\mathrm{r}_{\mathrm{a}}\left(\mathrm{R}_{\mathrm{n}}-\mathrm{G}\right)}{\mathrm{C}_{\mathrm{v}}} \frac{\gamma\left(1+\frac{\mathrm{r}_{\mathrm{cp}}}{\mathrm{r}_{\mathrm{a}}}\right)}{\Delta+\gamma\left(1+\frac{\mathrm{r}_{\mathrm{cp}}}{\mathrm{r}_{\mathrm{a}}}\right)}-\left(\frac{\mathrm{VPD}}{\Delta+\gamma\left(1+\frac{\mathrm{r}_{\mathrm{cp}}}{\mathrm{r}_{\mathrm{a}}}\right)}\right)
$$

where $r_{a}$ is the aerodynamic resistance $(\mathrm{s} / \mathrm{m}), \mathrm{R}_{\mathrm{n}}$ is the net radiation $\left(\mathrm{W} / \mathrm{m}^{2}\right), \mathrm{G}$ is the soil heat flux density $\left(\mathrm{W} / \mathrm{m}^{2}\right), \mathrm{C}_{\mathrm{v}}$ is the volumetric heat capacity of air $\left(\mathrm{J} /{ }^{\circ} \mathrm{C} \mathrm{m}^{3}\right), \gamma$ is the psychrometric constant $\left(\mathrm{kPa} /{ }^{\circ} \mathrm{C}\right), \mathrm{r}_{\mathrm{cp}}$ is the canopy resistances to vapor transfer for fully transpiring cover $(\mathrm{s} / \mathrm{m}), \mathrm{VPD}$ is the air vapor pressure deficit $(\mathrm{kPa})$, and $\Delta$ is the slope of the saturated vapor pressure-temperature relationship $\left(\mathrm{kPa} /{ }^{\circ} \mathrm{C}\right)$.

For water-stressed dense vegetation, the $\left(T_{S}-T_{A}\right)$ value was as follows:

$$
\left(\mathrm{T}_{\mathrm{s}}-\mathrm{T}_{\mathrm{A}}\right)_{2}=\frac{\mathrm{r}_{\mathrm{a}}\left(\mathrm{R}_{\mathrm{n}}-\mathrm{G}\right)}{\mathrm{C}_{\mathrm{v}}} \frac{\gamma\left(1+\frac{\mathrm{r}_{\mathrm{cx}}}{\mathrm{r}_{\mathrm{a}}}\right)}{\Delta+\gamma\left(1+\frac{\mathrm{r}_{\mathrm{cx}}}{\mathrm{r}_{\mathrm{a}}}\right)}-\left(\frac{\mathrm{VPD}}{\Delta+\gamma\left(1+\frac{\mathrm{r}_{\mathrm{cx}}}{\mathrm{r}_{\mathrm{a}}}\right)}\right)
$$

where $r_{c x}$ is canopy resistance to vapor transfer for fully stressed cover $(\mathrm{s} / \mathrm{m})$.

For water-saturated bare soil, where canopy resistance $r_{C}=0$, the $\left(T_{S}-T_{A}\right)$ was computed as follows:

$$
\left(\mathrm{T}_{\mathrm{s}}-\mathrm{T}_{\mathrm{A}}\right)_{3}=\frac{\mathrm{r}_{\mathrm{a}}\left(\mathrm{R}_{\mathrm{n}}-\mathrm{G}\right)}{\mathrm{C}_{\mathrm{V}}} \frac{\gamma}{\Delta+\gamma}-\left(\frac{\mathrm{VPD}}{\Delta+\gamma}\right)
$$


For dry bare soil, where $r_{c}=\infty$, it was estimated as follows:

$$
\left(\mathrm{T}_{\mathrm{s}}-\mathrm{T}_{\mathrm{A}}\right)_{4}=\frac{\mathrm{r}_{\mathrm{a}}\left(\mathrm{R}_{\mathrm{n}}-\mathrm{G}\right)}{\mathrm{C}_{\mathrm{v}}}
$$

The soil heat flux density $G$ was computed from $R_{n}$, with $G$ equal to $0.15 R_{n}$ for vegetation, $0.3 R_{n}$ for saturated bare soil, and $0.5 \mathrm{R}_{\mathrm{n}}$ for dry bare soil.

The WDI considers two important assumptions associated to the relationship between VIs and the difference $\left(\mathrm{T}_{\mathrm{S}}-\mathrm{T}_{\mathrm{A}}\right)$. The variations in $\left(\mathrm{T}_{\mathrm{S}}-\mathrm{T}_{\mathrm{A}}\right)$ would be associated to evapotranspiration (ET). Thus, for a partially vegetated area, WDI is as follows:

$$
\mathrm{WDI}=1-\frac{\mathrm{ET}}{\mathrm{E}_{\mathrm{pot}}}
$$

where $\frac{E T}{E_{p o t}}$ is the relative evapotranspiration, the ratio of effective to potential ET.

\subsubsection{Leaf Gas Exchange Measurements}

The net photosynthetic $\mathrm{CO}_{2}$ assimilation rate $\left(\mathrm{A}_{n}, \mu \mathrm{mol} / \mathrm{m}^{2} / \mathrm{s}\right)$ at saturating light, stomatal conductance to water vapor $\left(\mathrm{g}_{\mathrm{s}}, \mathrm{mol} / \mathrm{m}^{2} / \mathrm{s}\right)$, and transpiration was determined by using a portable open-system gas-exchange Li-6400 (Li-Cor Biosciences, Lincoln, NE, USA), with $\mathrm{CO}_{2}$ inside the leaf chamber set to $400 \mu \mathrm{mol} / \mathrm{mol}$ air by means of an external bottled $\mathrm{CO}_{2}$ source. An LED light source provided a photosynthetic photon flux density (PPFD) equal to $2000 \mu \mathrm{mol} / \mathrm{m}^{2} / \mathrm{s}$. Measurements were taken around noon time (from 11:00 to 13:00). Each measurement was replicated on six leaves per plot for each treatment.

\subsubsection{Biometric Measurements: Leaf Area Index and Dry Aboveground Biomass}

Leaf Area Index (LAI) of durum wheat was measured every 10-12 days. Plants from an area of $0.25 \mathrm{~m}^{2}$ per plot were collected on several sampling dates throughout the growing seasons. Then, they were subdivided in leaves and stems. From a subsample of leaves, leaf area was determined using the leaf area meter (Li-Cor, 3100 Lincoln, NE, USA). On the same sampling dates, the Dry Aboveground Biomass (DAGB) was measured after drying it in the oven at $70{ }^{\circ} \mathrm{C}$ until a constant weight was reached.

\subsection{Space-Borne Remote Sensing Measurements}

\subsubsection{Image Acquisition and Analysis}

Landsat 8 images were downloaded free of charge from the United States Geological Survey (USGS) Earth Resources Observation and Science (EROS) Centre archive website (http://earthexplorer.usgs.gov/). The images consisted of the Operational Land Imager (OLI) sensor and the Thermal Infrared Sensor (TIRS). The study area was covered by two Landsat 8 paths/rows: 188/32 and 187/32. For the first year, the satellite images were acquired from 07 April 2015 to 19 June 2015 using both Operational Land Imager and Thermal InfraRed sensors. Regarding the second year, imagery was downloaded from 09 April 2016 to 07 July 2016. It was not possible to use more images due to weather constraints (dense cloud presence).

Sentinel-2A image was collected on 30 April 2016. The imagery was downloaded from the Sentinels Scientific Data Hub, which provides unlimited open access to the Sentinel-2 Level-1C (L1C) user products. The L1C pixel values refer to the Top of Atmosphere (TOA) reflectance. The combination of data from these two sun-synchronous polar orbiting systems provided a global median average revisit interval of 4.6 days [58].

The Landsat 8 and Sentinel-2 imagery were analyzed through ENVI 5.1 software. As the Landsat 8 downloaded data are already geo-referred, no geometric calibration was performed. The alternative process was the radiometric calibration. Standard Landsat 8 L1T products are distributed by USGS 
EROS in 16 bits unsigned integer format and can be rescaled to top of atmosphere spectral reflectance and top of atmosphere spectral radiance using the radiometric rescaling coefficients provided in the product metadata (MTL) file. Landsat 8 operational land imager files were converted from Digital Number (DN) to Top of the Atmosphere (TOA) spectral data in terms of gains, offsets, solar irradiance, and sun elevation defined in the metadata. The brightness temperature option is available only for thermal imagery. The Landsat 8's two thermal bands were designed to allow the retrieval of surface temperature values, using the split-window algorithm. Subsequently, representative vegetation indices (VIs) were selected and derived.

The selected Sentinel-2 scene (30/04/2016) was cloud free; therefore, there was no requirement for performing cloud masking.

\subsubsection{Vegetation Indices Mapping}

A preliminary assessment of optical vegetation indices was carried out in order to study their potential as indicators of crop water status and to assess structural changes potentially caused by the irrigation regime.

The band sets used in each vegetation index, at pixel-based scale, included those centered at 654.5 and $865 \mathrm{~nm}$ for the NDVI, SAVI, and EVI calculations as well as for the LAI estimation. An overview of the spectral indices used in this study is presented in Table 1.

Table 1. Satellite-derived vegetation indices used in the study.

\begin{tabular}{cccc}
\hline Spectral Index & Abbreviation & Formula & Reference \\
\hline $\begin{array}{c}\text { Normalized Difference } \\
\text { Vegetation Index }\end{array}$ & NDVI & $\frac{(\mathrm{NIR}-\mathrm{R})}{(\mathrm{NIR}+\mathrm{R})}$ & Rouse and Haas [59] \\
\hline Soil Adjusted Vegetation Index & SAVI & $(1+\mathrm{L}) *\left(\frac{\mathrm{NIR}-\mathrm{R}}{\mathrm{NIR}+\mathrm{R}+\mathrm{L}}\right)$ & Huete [26] \\
\hline Enhanced Vegetation Index & EVI & $2.5 *\left(\frac{\mathrm{NIR}-\mathrm{R}}{\mathrm{NIR}+2.4 \mathrm{R}+1}\right)$ & Huete et al. [28] \\
\hline Leaf Area Index & LAI & $3.618 * \mathrm{EVI}-0.118$ & Boegh et al. [60] \\
\hline
\end{tabular}

L: SAVI adjustment factor, fixed at a standard value of 0.5 , as suggested by Huete [26].

\subsubsection{Land Surface Temperature Estimation-WDI Assessment}

The methodology adopted for the estimation of Land Surface Temperature (LST) and WDI is synthetized in a flowchart given in Figure 1.

Land surface temperature was retrieved from Landsat 8 thermal infrared sensor bands using the Split Window (SW) algorithm proposed by Jimenez-Munoz and Sobrino [61]:

$$
\mathrm{T}_{\mathrm{s}}=\mathrm{T}_{10}+\mathrm{c}_{1}\left(\mathrm{~T}_{10}-\mathrm{T}_{11}\right)+\mathrm{c}_{2}\left(\mathrm{~T}_{10}-\mathrm{T}_{11}\right)^{2}+\mathrm{c}_{0}+\left(\mathrm{c}_{3}+\mathrm{c}_{4} \mathrm{w}\right)(1-\varepsilon)+\left(\mathrm{c}_{5}+\mathrm{c}_{6} \mathrm{w}\right) \Delta \varepsilon
$$

where $\varepsilon$ is the mean emissivity $\varepsilon=0.5\left(\varepsilon_{\mathrm{i}}+\varepsilon_{\mathrm{j}}.\right), \Delta \varepsilon$ is the emissivity difference $\Delta \varepsilon=\left(\varepsilon_{\mathrm{i}}-\varepsilon_{\mathrm{j}}\right.$. $)$, W is the total atmospheric water vapor content $\left(\mathrm{g} / \mathrm{cm}^{2}\right)$, and $\mathrm{c}_{0}-\mathrm{c}_{6}$ are the Split Window coefficients.

Thermal infrared sensor data of both bands (10 and 11) of all the Landsat images were converted into spectral radiance as mentioned above. The retrieved radiance was converted into brightness temperature $\left(\mathrm{T}_{\mathrm{B}}\right)$ using the thermal constants provided in the Landsat metadata.

Brightness temperature (in Kelvin), for each pixel within the extracted region, was applied as follows:

$$
\mathrm{T}_{\mathrm{B}}=\frac{\mathrm{K}_{2}}{\ln \left(\frac{\mathrm{K}_{1}}{\mathrm{~L}_{\lambda}}+1\right)}
$$

where $\mathrm{T}_{\mathrm{B}}$ is the at-satellite brightness temperature $(\mathrm{K}) ; \mathrm{L}_{\lambda}$ is the TOA spectral radiance $\left(\mathrm{W} / \mathrm{m}^{2} / \mathrm{srad} / \mu \mathrm{m}\right)$; and $K_{1}$ and $K_{2}$ are the band-specific thermal conversion constants (Table 2). 
Table 2. Specific thermal conversion constants for bands 10 and 11 of Landsat 8 .

\begin{tabular}{ccc}
\hline & \multicolumn{2}{c}{ Specific Thermal Conversion Constants } \\
\hline & $\mathbf{K}_{\mathbf{1}}$ & $\mathbf{K}_{\mathbf{2}}$ \\
\hline Band 10 & 774.89 & 1321.08 \\
\hline Band 11 & 480.89 & 1201.14 \\
\hline
\end{tabular}

Source: The metadata file delivered with the Landsat 8 image.

The split-window coefficients $c_{0}$ to $c_{6}$ (Table 3 ) were extracted from simulated data reported by Skokovic et al. [62].

Table 3. Split window coefficient values.

\begin{tabular}{cc}
\hline $\mathbf{c}_{\boldsymbol{0}}$ & -0.268 \\
\hline $\mathbf{c}_{\mathbf{1}}$ & 1.378 \\
\hline $\mathbf{c}_{\mathbf{2}}$ & 0.183 \\
\hline $\mathbf{c}_{\mathbf{3}}$ & 54.30 \\
\hline $\mathbf{c}_{\mathbf{4}}$ & -2.238 \\
\hline $\mathbf{c}_{\mathbf{5}}$ & -129.2 \\
\hline $\mathbf{c}_{\mathbf{6}}$ & 16.40
\end{tabular}

In this study, the land surface temperature retrieval method was used with previously known Land Surface Emissivity (LSE), since the simultaneous methods need specific requirements and sophisticated algorithms, while the previously known land surface emissivity methods appear to be more practical with reasonable accuracy for land surface temperature retrieval from Landsat imagery. Emissivity $(\varepsilon)$ is estimated following NDVI thresholds method retrieved using Sobrino et al. [63,64] and Wang et al. [65].

$$
\varepsilon_{\mathrm{i}}=\left\{\begin{array}{lc}
\mathrm{a}_{\mathrm{i}} \rho_{\mathrm{red}}+\mathrm{b}_{\mathrm{i}} ; & \mathrm{NDVI}<0.2 \\
\varepsilon_{\mathrm{V}, \mathrm{i}} \mathrm{P}_{\mathrm{v}}+\varepsilon_{\mathrm{s}, \mathrm{i}}\left(1-\mathrm{P}_{\mathrm{v}}\right)+\mathrm{C}_{\mathrm{i}} ; & 0.2<\mathrm{NDVI}<0.5 \\
\varepsilon_{\mathrm{V}, \mathrm{i}}+\mathrm{C}_{\mathrm{i}} ; & \text { NDVI }>0.5
\end{array}\right.
$$

The emissivity of vegetation $\left(\varepsilon_{\mathrm{v}}\right)$ and soil $\left(\varepsilon_{\mathrm{s}}\right)$ was calculated from the Moderate Resolution Imaging Spectroradiometer (MODIS) UCSB (University of California, Santa Barbara) emissivity library, using the following equation:

$$
\varepsilon_{\mathrm{i}}=\frac{\int_{\lambda 1, \mathrm{i}}^{\lambda 2 \mathrm{i}} \mathrm{f}_{\mathrm{i}}(\lambda)-\varepsilon_{\mathrm{i}}(\lambda) \mathrm{d} \lambda}{\int_{\lambda 1, \mathrm{i}}^{\lambda 2, \mathrm{i}} \mathrm{f}_{\mathrm{i}}(\lambda) \mathrm{d} \lambda}
$$

where $\varepsilon_{\mathrm{i}}$ is the emissivity for channel $\mathrm{I}, \varepsilon_{\mathrm{i}}(\lambda)$ is the spectral emissivity, $\lambda_{\mathrm{i}}$ is the effective band wavelength for band $\mathrm{I}$, and $\mathrm{f}_{\mathrm{i}}(\lambda)$. is the spectral response function for correspondent band.

Soil and vegetation emissivity's values for Landsat 8 TIRS are reported in Table 4.

Table 4. Emissivity of soil and vegetation for Landsat 8 thermal infrared sensor bands 10 and 11.

\begin{tabular}{ccc}
\hline & \multicolumn{2}{c}{ Emissivity } \\
\hline & Soil & Vegetation \\
\hline Band 10 & 0.9668 & 0.9863 \\
\hline Band 11 & 0.9747 & 0.9896 \\
\hline
\end{tabular}


The vegetation fraction $\left(\mathrm{P}_{\mathrm{v}}\right)$ is derived from NDVI $[63,66]$ :

$$
\mathrm{P}_{\mathrm{v}}=\left(\frac{\mathrm{NDVI}-\mathrm{NDVI}_{\min }}{\mathrm{NDVI}_{\max }-\mathrm{NDVI}_{\min }}\right)^{2}
$$

where $\mathrm{NDVI}_{\min }=0.2$ and $\mathrm{NDVI}_{\max }=0.5$.

$C_{i}$ is a term which considers the cavity effect due to the surface roughness ( $C=0$ for flat surfaces). Sobrino et al. [67] suggested that $C_{i}$ can be estimated as follows:

$$
\mathrm{C}_{\mathrm{i}}=\left(1-\varepsilon_{\mathrm{s}, \mathrm{i}}\right) \varepsilon_{\mathrm{V}, \mathrm{i}} \mathrm{F}^{\prime}\left(1-\mathrm{P}_{\mathrm{v}}\right)
$$

where $\mathrm{F}^{\prime}$ is the geometrical factor ranging between 0 and 1 , depending on the geometrical distribution of the surface (usually 0.55).

When NDVI $<0.2$ (never occurred in this experiment), the pixel was considered as bare soil $\left(P_{v}=0\right)$. For this circumstance, the emissivity was estimated from an empirical relationship with the red band reflectance $(R)$, which is also derived from MODIS UCSB emissivity library $[64,68,69]$. The relationships for band 10 and 11 were $\varepsilon_{10}=0.973-0.047 \mathrm{R}$ and $\varepsilon_{11}=0.984-0.026 \mathrm{R}$.

Different vegetation indices such as NDVI, MSAVI, and SAVI may have different linkages with land surface temperature providing the design basis of the vegetation index/temperature trapezoid. In this research, the NDVI was utilized since it shows more sensitivity to partial covers in early stages of the crop. The corners of the vegetation index/temperature trapezoid were determined using the measured values of wheat NDVI during several crop stages under conditions of rainfed and full irrigation and the difference between surface and air temperature. For a given pixel, we combined visible, infrared, and thermal datasets. The correlation between three bands has proven to be useful for appropriate monitoring of vegetation and water stress. Then, the vertices were defined and the empirical vegetation index/temperature trapezoid was built. It led to the definition of the WDI.

The WDI is developed to combine the NDVI and land surface temperature data to detect changes in moisture conditions. In this study, the Landsat 8 land surface temperature vs. NDVI relationship in terms of irrigation regimes is interpreted via the vegetation index/temperature trapezoid, which is a simplification of the WDI model.

\subsection{Statistical Analysis}

Linear regression analysis was applied to assess the relationship between crop physiological and biometric data and vegetation indices, whereas the exponential regression analysis was used to evaluate the relationship between the ground-based and satellite-based vegetation indices. The coefficient of determination $\left(R^{2}\right)$ was considered to judge the strength of relationships.

All statistical analyses were carried out using SAS University Edition (Cary, NC, USA).

\section{Results and Discussion}

\subsection{Ground-Based Sensing Results}

\subsubsection{Leaf Gas Exchange Parameters Versus VIs Measured at Canopy Scale}

The parameters of the linear regressions linking the measured gas exchange variables (stomatal conductance, net assimilation. and transpiration rate), with thermal (WDI) and spectral (NDVI, SAVI, and EVI) VIs are presented in Figures 2 and 3, respectively. The linear regression function was chosen since it was applied successfully in several other studies [70-73]. 


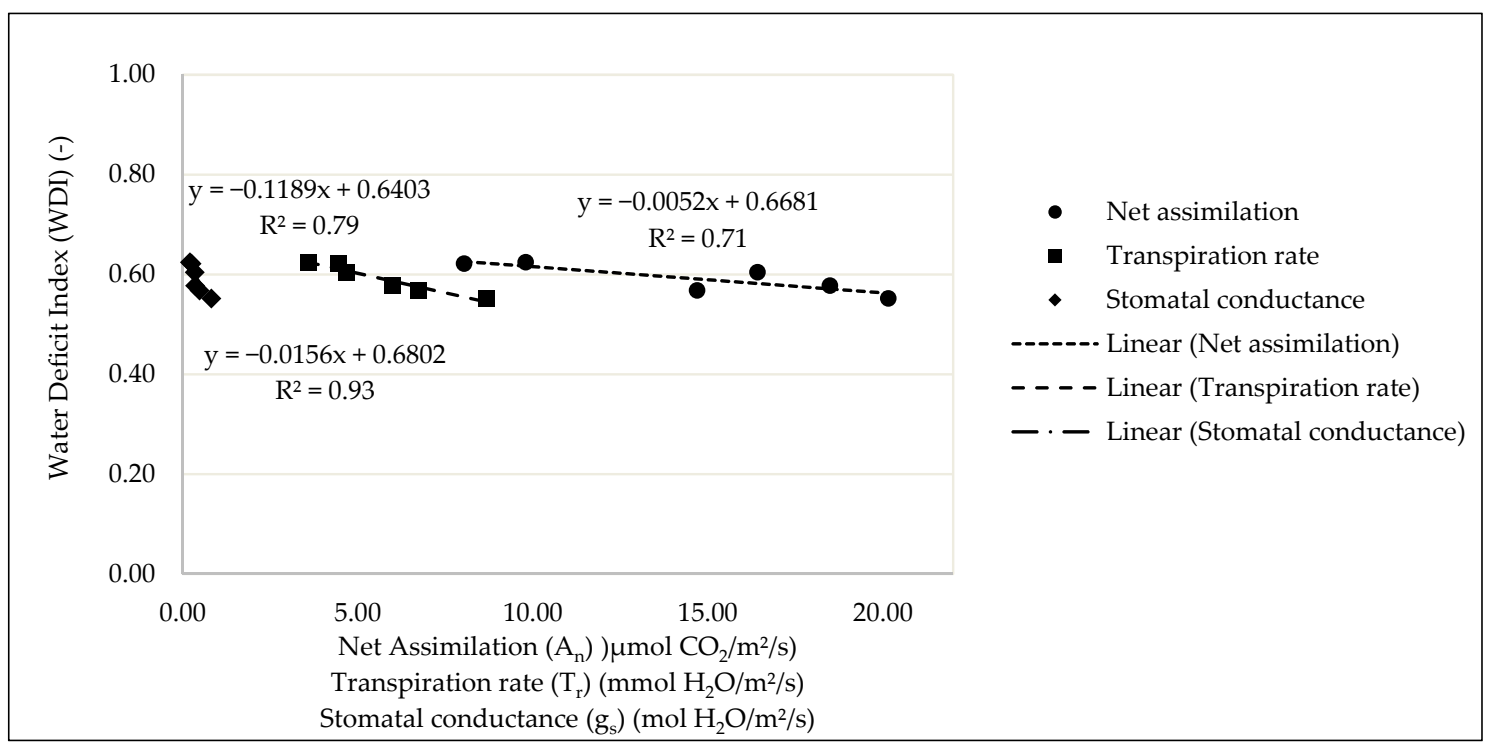

Figure 2. The parameters of linear regression $\left(R^{2}\right.$-correlation coefficient) between leaf gas exchange variables ( $\mathrm{g}_{\mathrm{s}}$-stomatal conductance, $\mathrm{A}_{\mathrm{n}}$ —net assimilation, and $\mathrm{T}_{\mathrm{r}}$-transpiration rate) and the thermal index (WDI-Water Deficit Index)).

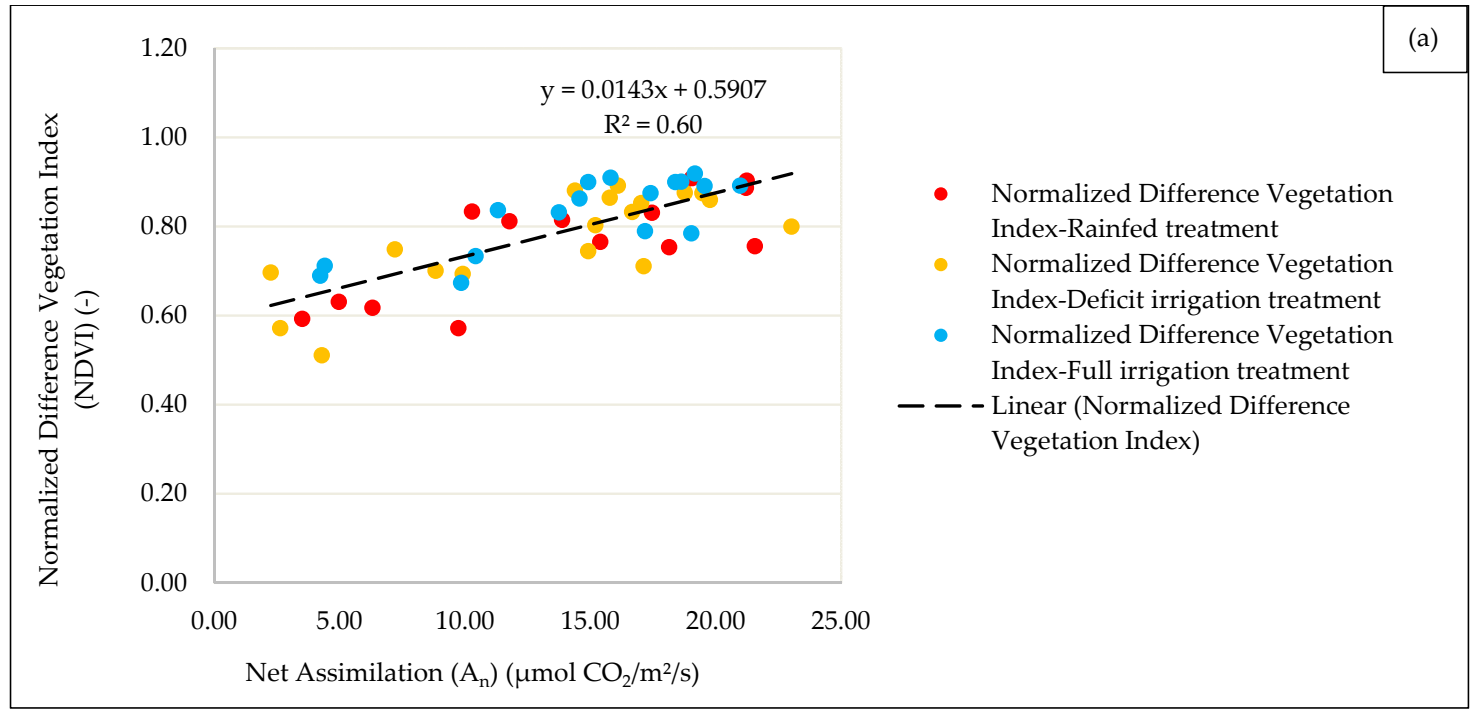

Figure 3. Cont. 

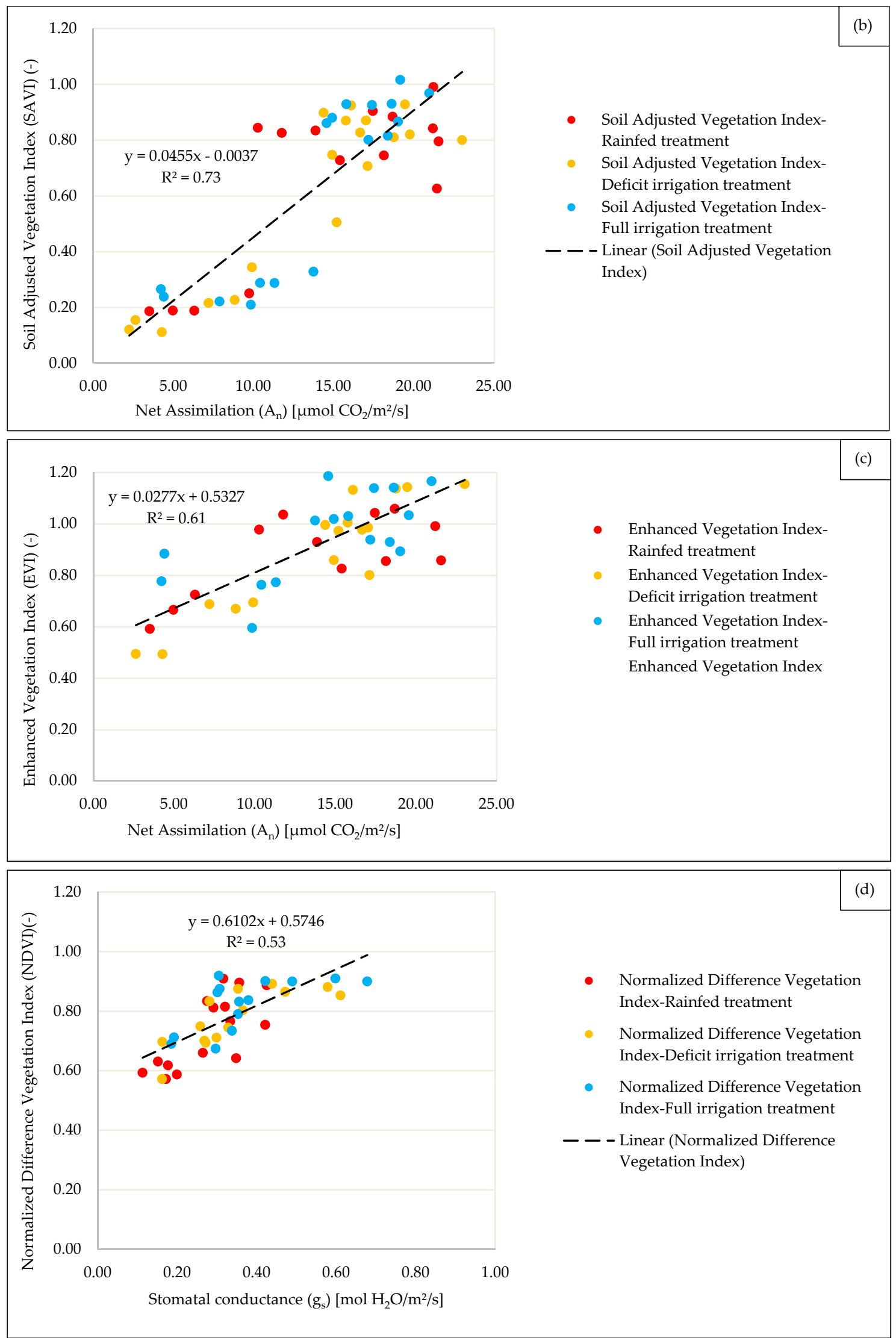

Figure 3. Cont. 

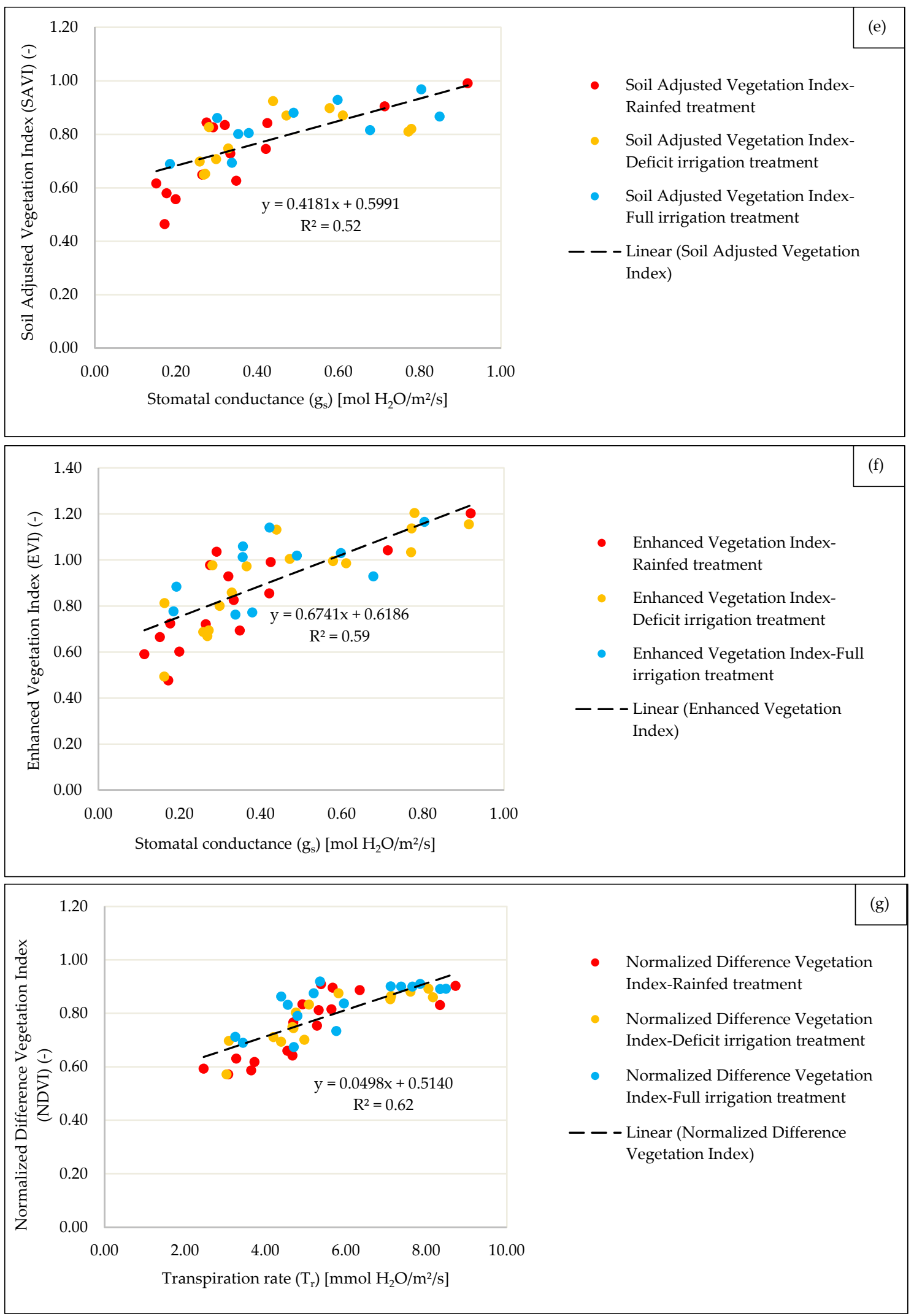

Figure 3. Cont. 

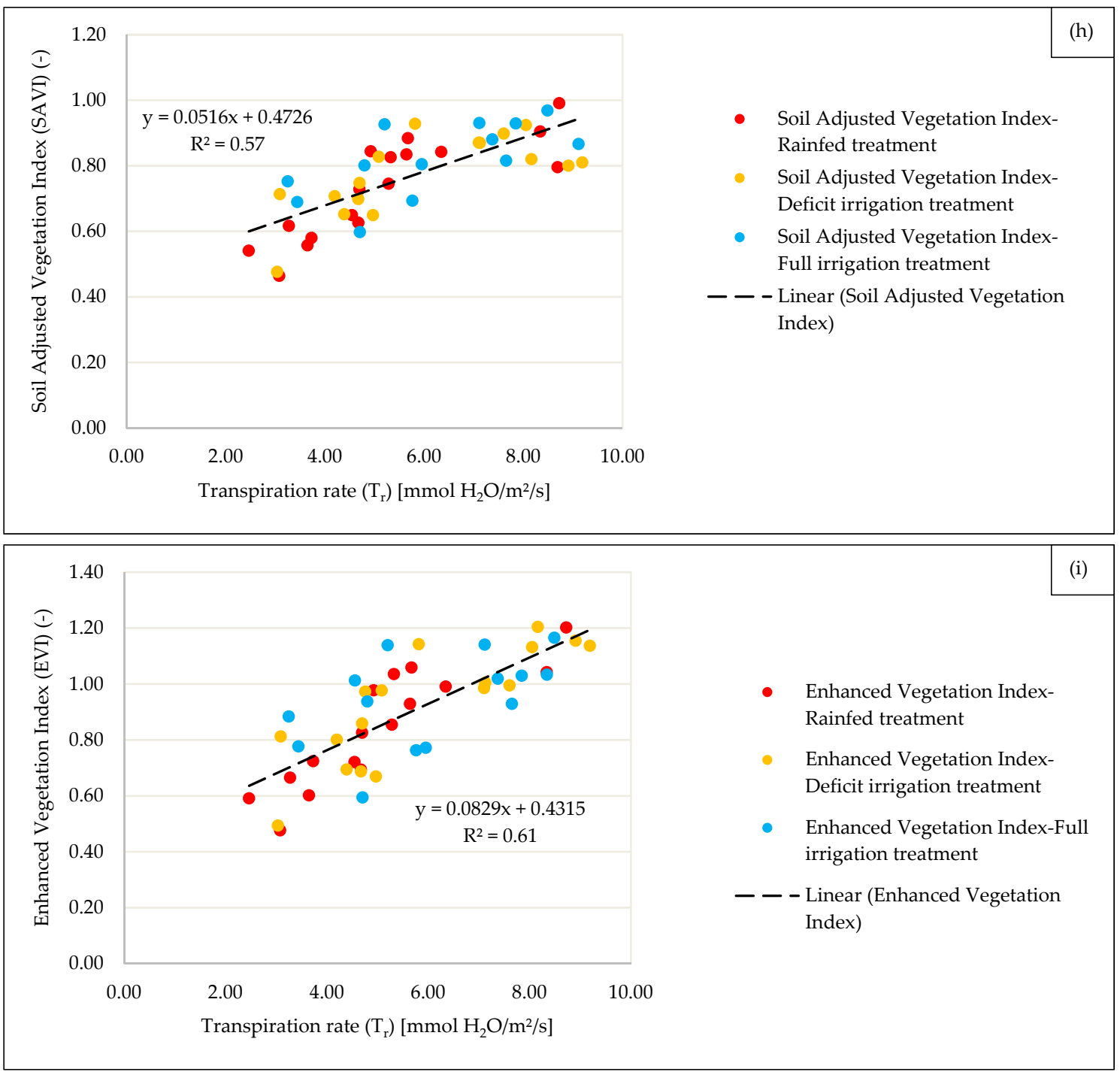

Figure 3. Linear regression parameters between net assimilation $(\mathbf{a}-\mathbf{c})$, stomatal conductance $(\mathbf{d}-\mathbf{f})$ and transpiration rate (g-i) leaf exchange parameters and spectral (Normalized Difference Vegetation Index (NDVI), Soil Adjusted Vegetation Index (SAVI), and Enhanced Vegetation Index (EVI)) vegetation indices, respectively.

Overall, the optical-based Leaf Gas Exchanges (LGE) models performed consistently well. A positive correlation between leaf gas exchanges and NDVI, SAVI, and EVI was observed. Nevertheless, a negative correlation between leaf gas exchanges and WDI was apparent. The $\mathrm{R}^{2}$ of VI-based leaf gas exchange estimation ranged from 0.52 to 0.75 . EVI demonstrated slightly better performance than SAVI and NDVI (Figure 3). Under these circumstances, WDI was found to perform strongly with the abovementioned parameters, since surface temperature $\left(T_{s}\right)$ measurements were reliable in determining the four corners of the vegetation index/temperature trapezoid data-range. It was shown that the thermal information had a stronger capacity of estimating leaf gas exchanges than optical data.

The ability of optical-based and thermal-based data to estimate leaf gas exchanges was evaluated. Land surface temperature provided valuable information to quantify surface energy balance, and it is theoretically linked with leaf gas exchanges in the form of WDI [74,75]. NDVI, SAVI, and EVI were the indicators of the trend term, whereas WDI was the indicator describing environmental stress. Zhang [76] and Yang et al. [77] used temperature information to measure the influence of drought stress on stomatal conductance. Therefore, employing thermal information as a vital proxy for drought stress is a good alternative. Overall, the presented results demonstrated that the application of optical 
VIs to estimate leaf gas exchanges is a promising methodology. In particular, good results were observed when WDI was correlated with stomatal conductance $\left(R^{2}=0.93\right)$ and other LGE parameters (Figure 2). If the thermal information is missing, single optical VIs is also recommended to quantify leaf gas exchanges.

There is not a clear differentiation of results among different water regimes (Figure 3). It might be explained by the relatively low irrigation amount (1050 and $960 \mathrm{~m}^{3} /$ ha in 2015 and 2016, respectively) which was applied mainly at the flowering and yield formation phases. Therefore, there was enough precipitation during the booting and stem elongation phase which impeded the occurrence of water stress during crop vegetative development. Accordingly, the VIs could not be suitable to discern among different water regimes.

\subsubsection{Biometric Crop Parameters Versus VIs Measured at Canopy Scale}

The regressions derived from the relationships between canopy scale vegetative indices (i.e., NDVI, SAVI, and EVI) versus biometric crop parameters (leaf area index and dry aboveground biomass) are summarized in Figure 4. A linear regression function was chosen to show the general trend of the above-cited relationships.

The results (Figure 4) indicated that the measured vegetation indices are correlated with LAI to a certain level of agreement. Hence, in the case of LAI, $\mathrm{R}^{2}$ ranges between 0.63 (for NDVI) and 0.73 (for both SAVI and EVI).

Up to the initiation of flowering, the averaged LAI increased in all plots, but it started to decrease at the beginning of yield formation and maturity. In this study, both ground-based and satellite mean hyperspectral reflectance of wheat canopy increased at the beginning of the season and then started to decrease, which is consistent with the field measurements of LAI. The present results suggest that LAI can be accurately estimated using spectral vegetation indices. Inasmuch as EVI was significantly affected by soil background, it was strongly correlated with leaf area index $\left(R^{2}=0.73\right)$. This result is in agreement with Fensholt et al. [78], who reported similar findings on grassland.

The results of regression analysis between winter wheat biomass and spectral vegetative indices showed that all measured vegetation indices are correlated with biomass to a certain level of agreement (Figure 4). The correlation of Dry Aboveground Biomass (DAGB) was better with EVI $\left(R^{2}=0.65\right)$ than with SAVI $\left(R^{2}=0.60\right)$ and with NDVI $\left(R^{2}=0.56\right)$.

Previous studies have shown that near infrared and red band vegetation indices are effective for estimating DAGB [79-81]. Nevertheless, in this research, the correlation between DAGB, and red and near infrared band vegetation indices is not particularly strong. This can be explained by the fact that, during the reproductive stage, photosynthesis and near infrared reflectance both clearly decrease. This result is consistent with the results of Humbeck et al. [82]. Sun et al. [83] reported that, during the middle and late stages of crop growth, wheat reproductive growth was enhanced when the vegetative growth was weakened [84] and that, consequently, the winter wheat Dry Aboveground Biomass (DAGB) continued to increase. However, the chlorophyll content of winter wheat leaves decreased, leading to a decrease in the near infrared reflectance. The relation between near infrared spectral reflectance and crop biomass was then decreased because of the incoming senescence.

Yue et al. [85] reported that red-, green-, and blue-band spectral indices are effective in estimating Dry Aboveground Biomass (DAGB) of winter wheat during vegetative growth and reproductive growth stages.

\subsection{Satellite Sensing Results}

Mapping Leaf Area Index

The LAI maps are shown in Figure 5 for two days (around flowering and maturity) in the first agricultural year. For 16 April 2015, the satellite-based LAI data showed that the LAI was high in all 
plots. However, the LAI decreased near maturation (03 June 2015). These results are consistent with field observations and data reported by Yue et al. [85].
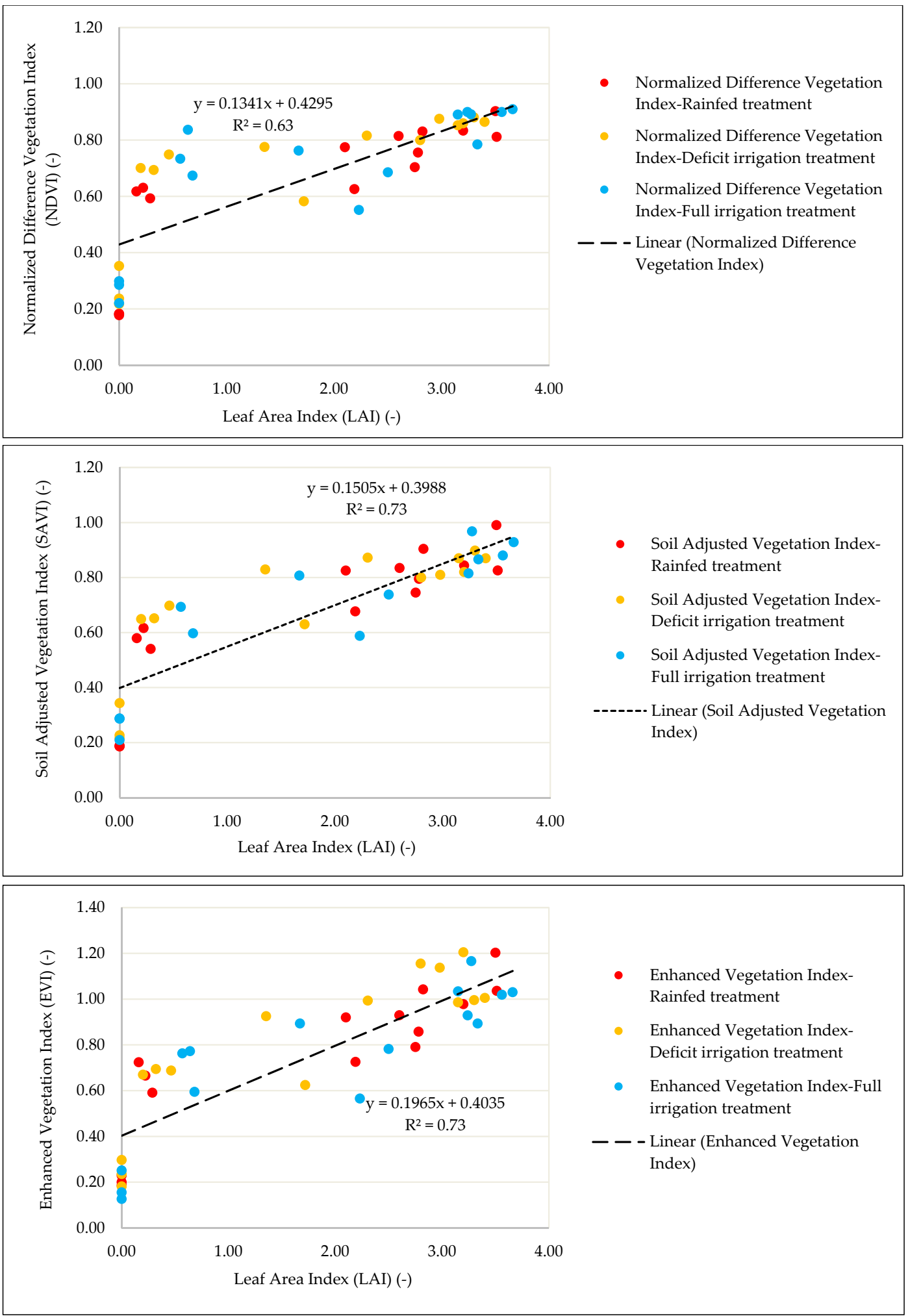

Figure 4. Cont. 

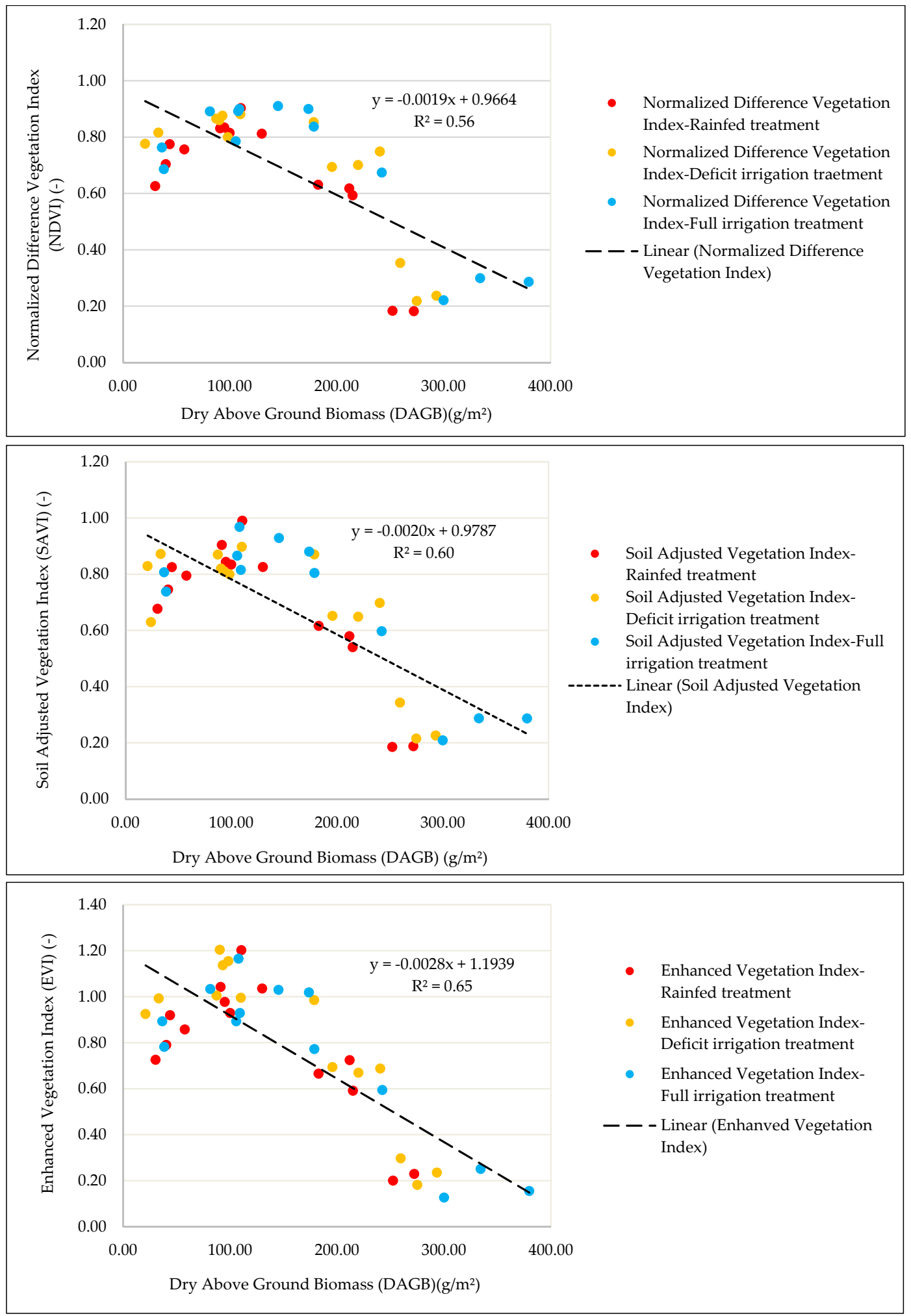

Figure 4. Linear regression parameters between the crop biometric parameters leaf area index and dry aboveground biomass and the spectral vegetation indices (NDVI, SAVI, and EVI). 

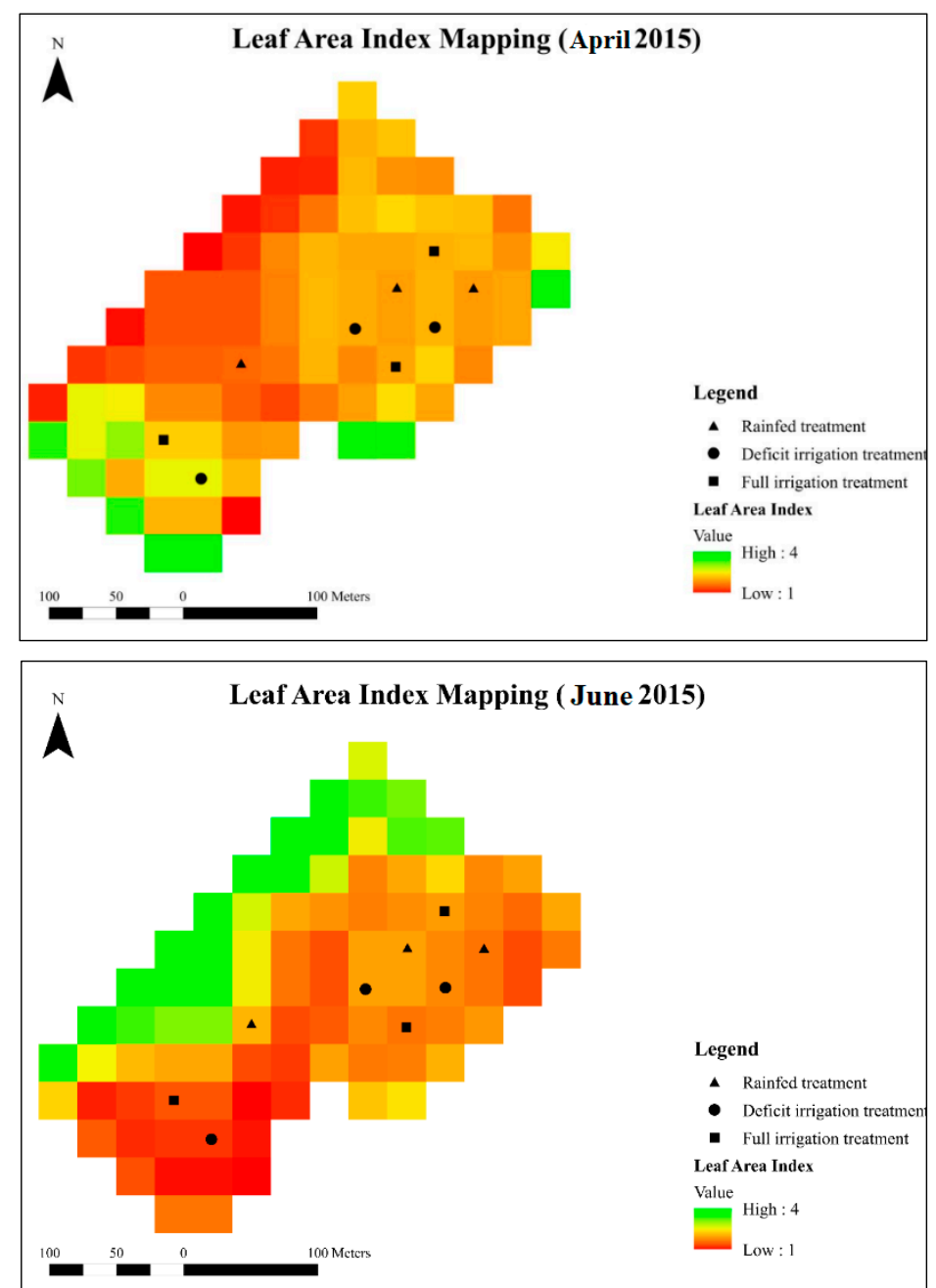

Figure 5. Leaf Area Index (LAI) maps made using LANDSAT 8 on 16 April and 03 June 2015.

\subsection{Satellite vs. Ground-Based VIs Comparison}

The type of relationships between LAI, NDVI, SAVI, and EVI measured from satellite and the same parameters measured from ground-based sensing method are given in Figure 6 for both years.

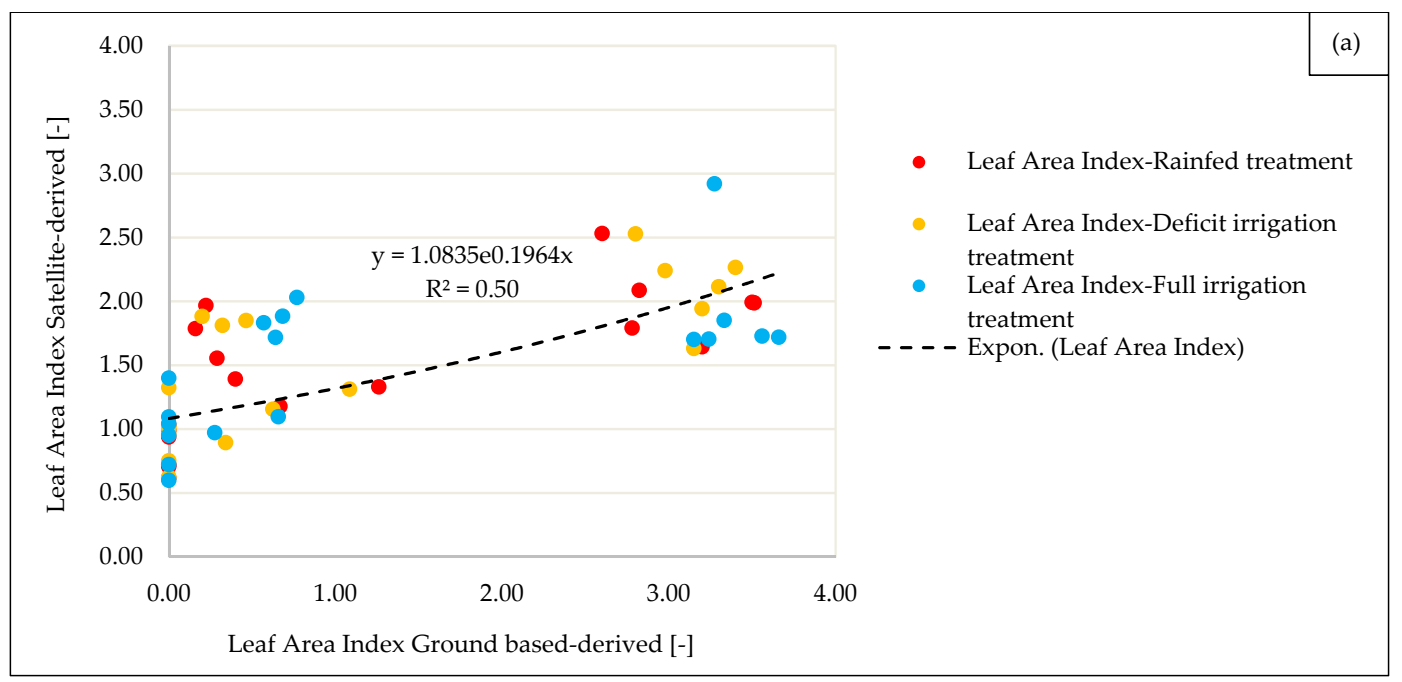

Figure 6. Cont. 

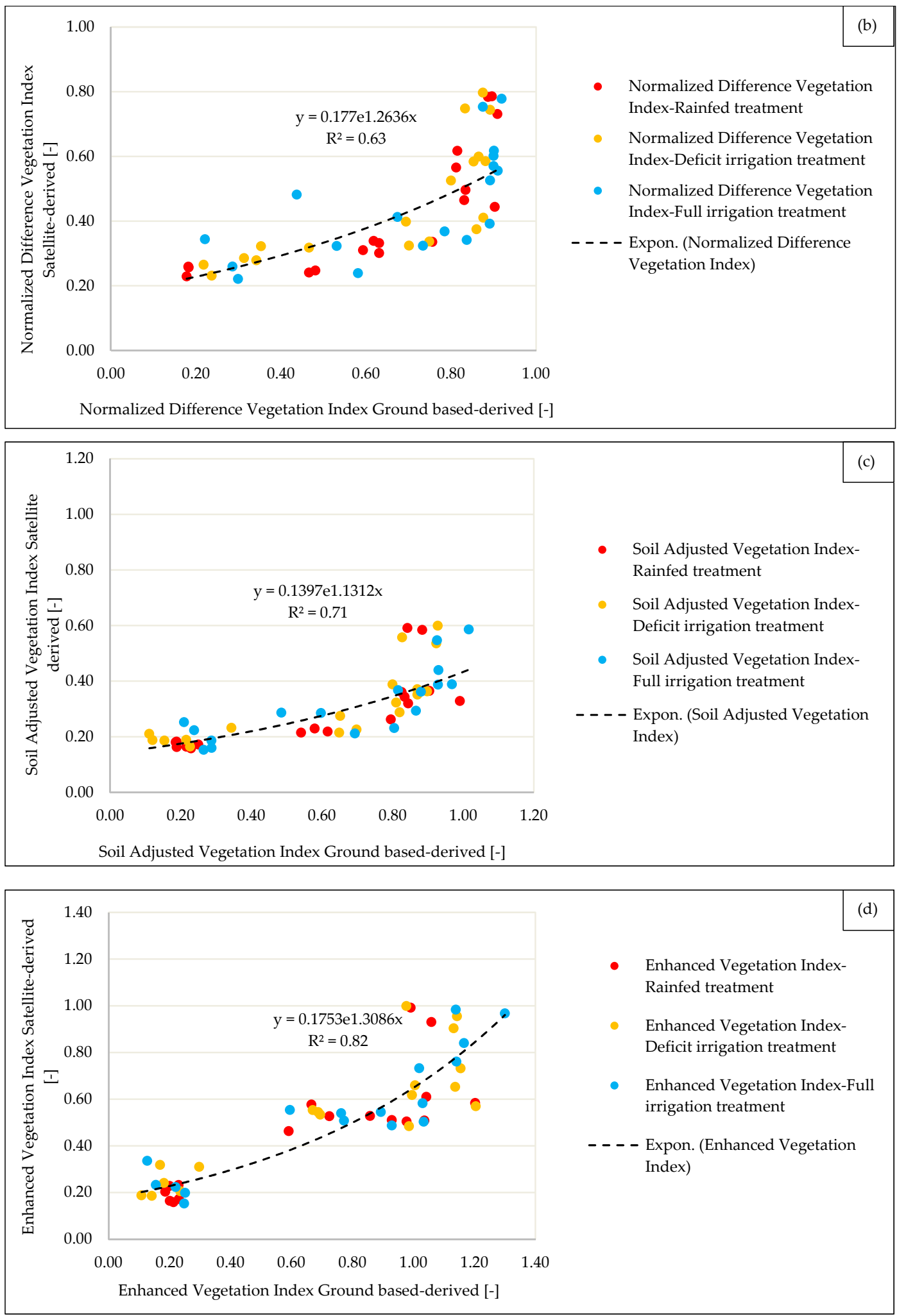

Figure 6. The relationship between satellite (Landsat 8) and ground-based LAI (a) and vegetative indices (NDVI (b), SAVI (c), and EVI (d)).

The exponential regression function was chosen to show the general trend of the LAI, NDVI, SAVI, and EVI VIs. High correlations appeared to be evident for LAI, NDVI, SAVI, and EVI regressions, with $R^{2}$ values close to or higher than 0.70 . The highest determination coefficient $\left(R^{2}=0.83\right)$ was 
obtained in the case of EVI. Again, there is no clear differentiation among different water regimes due to the facts explained previously in Section 3.1.1.

Biudes et al. [86] reported that LAI estimated on ground-based and satellite-derived extinction were positively correlated with crop growth. The NDVI correlation was relatively high, in agreement with other studies [87-89].

This study has confirmed the applicability of both ground-based and satellite remote sensing techniques to evaluate crop growth and plant physiological parameters of winter wheat. The VIs obtained on the ground-based measurements performed slightly better than those acquired by the satellite sensors.

Landsat and Sentinel 2 remote sensing data could be particularly useful for the regional assessments and field crops grown on large plots since these data cover greater areas and are available free of charge. Inasmuch as the limitations are related to the spatial resolution and revisiting frequency, the Landsat data offered a valuable input to assess winter wheat biometric and physiological parameters. Moreover, Landsat and Sentinel 2 data can be used in a complementary way. The limitation of use of satellite data under cloud conditions does not represent a serious drawback in the arid and semiarid areas of the Mediterranean region despite the cloud presence and precipitation. Therefore, the availability of Landsat and Sentinel 2 data provides the opportunity to develop specific operational tools, based on the historical earth observation sensing data and wheat management practices on the ground, to analyze the pros and cons of adopted agronomic practices in the past and to identify the best crop management for the future. Although a new generation of satellites with improved spatial resolution and reduced return frequency is available, the use of Landsat data remains essential due to the longest continuously running global data archive and the possibility to analyze the crop performance for a long period in the past.

Figure 7 shows the VIT trapezoid formed for winter wheat from ground-based and satellite data obtained for the first experimental year (2014-2015). The circles within the trapezoid correspond to measurements of $\left(T_{S}-T_{A}\right)$ and NDVI from the area planted with wheat. Both sensing methods were used to verify that all samples fell within the limits of the empirical trapezoid. The data showed either high or low values of NDVI and $\left(T_{\mathrm{S}}-\mathrm{T}_{\mathrm{A}}\right)$; some intermediate values were also recorded.

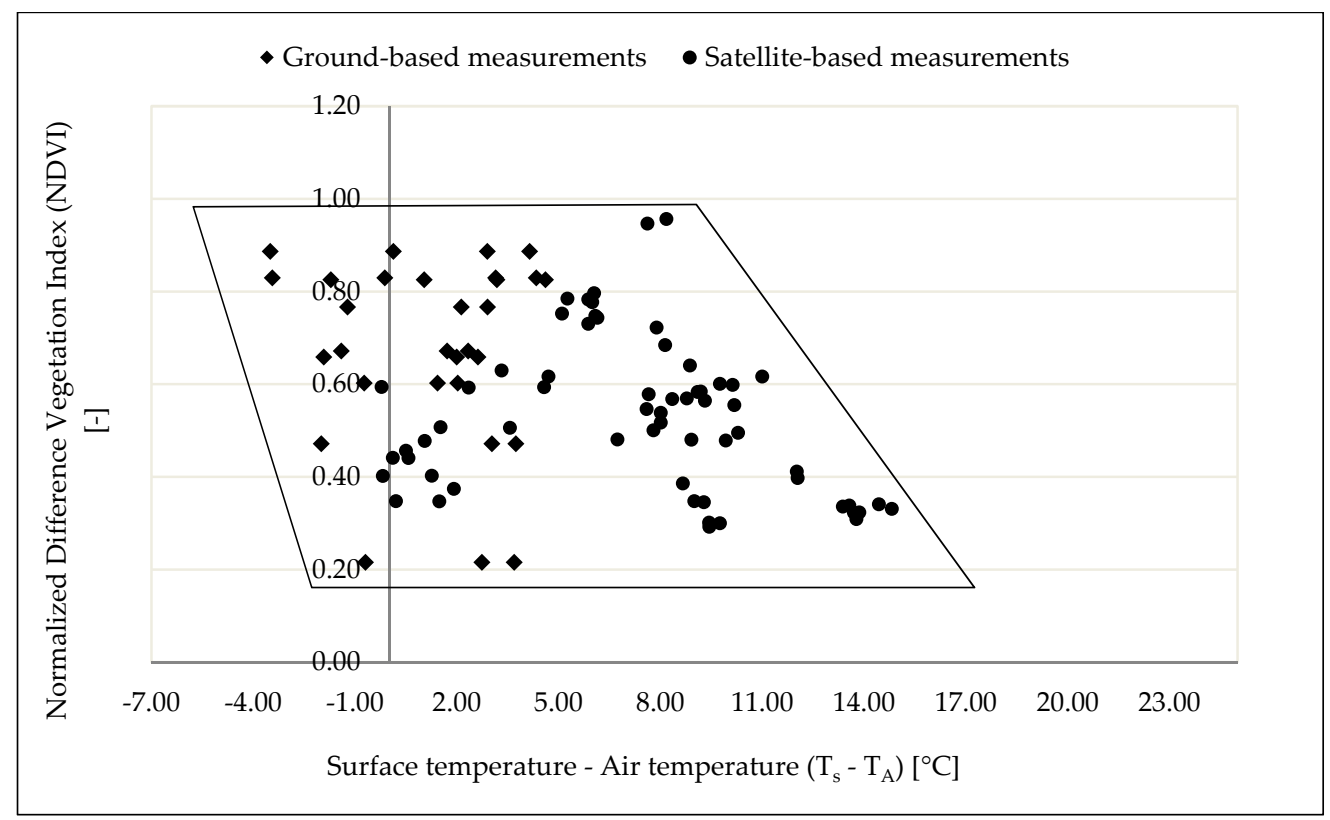

Figure 7. Vegetation Index/Temperature (VIT) trapezoid estimated for winter wheat from ground-based and satellite data.

The surface temperature values, measured to define the trapezoidal method for winter wheat, agree with those reported by Jackson [90], Moran et al. [47], and Mendez-Barroso et al. [91]. They mentioned 
that the temperature of dry bare soil is always several degrees above the air temperature, generally by more than $10-15{ }^{\circ} \mathrm{C}$, because the soil thermal inertia is relatively low [92] and soil moisture is one of the factors affecting the thermal properties of the soil.

The empirical trapezoid model proposed in this study can be a useful tool to estimate the spatial and temporal extent of WDI, which is applied to identify the degree of water stress. The development of this remote sensing method is a priority in arid and semiarid zones where water is a scarce resource. Moreover, it requires a reduced number of inputs, which are relatively easy to obtain, such as NDVI, air, and surface temperatures. Generally, WDI produced a good estimation of surface temperature and, thus, evapotranspiration because it was able to capture the growth process of leaves and to describe the temporal variation trend of stomatal conductance.

\section{Conclusions}

In this study, ground-based and satellite remote sensing techniques were used to evaluate and to compare crop growth and crop water status of winter wheat under three water regimes. The results of elaborations of data from two growing seasons indicated the following:

- A strong correlation between the spectral vegetative indices (NDVI, SAVI, and EVI) and LAI at the canopy scale. However, the relationship with dry aboveground biomass was less convincing. As related to leaf gas exchange parameters, WDI responded well to the increasing level of water stress. Data in the thermal infrared spectrum were the most promising source to monitor water stress, showing better correlations than the spectral vegetative indices.

- Despite the challenges posed by moderate satellite spatial resolution, the correlations between the satellite and ground-based results were satisfactory and consistent with other studies.

- The Vegetation Index/Temperature (VIT) trapezoid concept, based on Landsat 8 thermal bands and surface temperature data, constitutes a relevant approach to estimate the spatial and temporal extent of water stress. Nevertheless, it is more suitable for summer than for winter-spring crops.

Agricultural sector requires continuous monitoring systems able to provide timely data on crop growth, water/nutrient/health status, and biomass/yield in a standardized and regular manner at different scales (farm, regional, and national). The estimates should be provided as early as possible during the growing season(s), compared with the previous seasons, and updated periodically throughout the season until harvesting. The availability of remote sensing data should enable the agricultural engineers and water managers to identify the areas with the large variation of crop biometric and physiological parameters and to make adequate management decisions in order to stabilize and to improve yield and water productivity.

Author Contributions: Conceptualization, V.C., R.A. and M.T.; methodology, N.M., G.D.M. and M.T.; experimental measurements, N.M.; software, N.M.; formal analysis, N.M. and S.M.H.; writing-original draft preparation, N.M.; writing-review and editing, N.M., V.C., R.A. and M.T.; supervision, V.C., R.A. and M.T. All authors have read and agreed to the published version of the manuscript.

Funding: This research was carried out under the Master of Science Program on "Sustainable water and land management in Mediterranean agriculture" funded by CIHEAM - Mediterranean Institute of Bari.

Acknowledgments: The research was supported by the Master of Science Program in Land and Water Resources Management of CIHEAM-IAMB (Bari, Italy). The authors thank Carlo Ranieri, Domenico Tribuzio and Mohamed Ben Brahim (CIHEAM-IAMB) for technical support during the acquisition of data and Giovanni Manolio (experimental farm "E. Pantanelli") for agronomic assistance in the field.

Conflicts of Interest: The authors declare no conflict of interest.

\section{References}

1. Liu, P. A survey of remote-sensing big data. Front. Environ. Sci. 2015, 3, 1-6. [CrossRef]

2. Chi, M.; Plaza, A.; Benediktsson, J.A.; Sun, Z.; Shen, J.; Zhu, Y. Big data for remote sensing: Challenges and opportunities. Proc. IEEE 2016, 104, 2207-2219. [CrossRef] 
3. Khanal, S.; John, F.; Scott, S. An overview of current and potential applications of thermal remote sensing in precision agriculture. Comput. Electron. Agric. 2017, 139, 22-32. [CrossRef]

4. Huang, Y.; Zhong-Xin, C.; Tao, Y.; Xiang-Zhi, H.; Xing-Fa, G. Agricultural remote sensing big data: Management and applications. J. Integr. Agric. 2018, 17, 1915-1931. [CrossRef]

5. Gebbers, R.; Adamchuk, V.I. Precision agriculture and food security. Science 2010, 327, 828-831. [CrossRef] [PubMed]

6. Jovanovic, N.; Pereira, L.S.; Paredes, P.; Pôças, I.; Cantore, V.; Todorovic, M. A review of strategies, methods and technologies to reduce non-beneficial consumptive water use on farms considering the FAO56 methods. Agric. Water Manag. 2020, 239, 106267. [CrossRef]

7. Sakamoto, T.; Gitelson, A.A.; Arkebauer, T.J. MODIS-based corn grain yield estimation model incorporating crop phenology information. Remote Sens. Environ. 2013, 131, 215-231. [CrossRef]

8. Solano, R.; Didan, K.; Jacobson, A.; Huete, A. MODIS Vegetation Index User's Guide (MOD13 Series). In Vegetation Index and Phenology Lab, 2nd ed.; The University of Arizona: Tucson, AZ, USA, 2010.

9. Bulcock, H.H.; Jewitt, G.P.W. Spatial mapping of leaf area index using hyperspectral remote sensing for hydrological applications with a particular focus on canopy interception. Hydrol. Earth Syst. Sci. 2010, 14, 383-392. [CrossRef]

10. Chéret, V.; Denux, J.P. Analysis of Modis NDVI time series to calculate indicators of Mediterranean forest fire susceptibility. Gisci. Remote Sens. 2011, 48, 171-194. [CrossRef]

11. Sims, N.C.; Colloff, M.J. Remote sensing of vegetation responses to flooding of a semi-arid floodplain: Implications for monitoring ecological effects of environmental flows. Ecol. Indic. 2012, 18, 387-391. [CrossRef]

12. Johansen, B.; Tommervik, H. The Relationship between Phyto-mass, NDVI and Vegetation Communities Svalbard. Int. J. Appl. Earth Obs. Geoinf. 2014, 27, 20-30. [CrossRef]

13. Eckert, S.; Hüsler, F.; Liniger, H.; Hodel, E. Trend analysis of MODIS NDVI time series for detecting land degradation and regeneration in Mongolia. J. Arid Environ. 2015, 113, 16-28. [CrossRef]

14. Basso, B.; Cammarano, D.; De Vita, P. Remotely sensed vegetation indices: Theory and applications for crop management. Rivista Italiana Di Agrometeorologia 2004, 1, 36-53.

15. Panda, S.S.; Ames, D.P.; Panigrahi, P. Application of Vegetation Indices for Agricultural Crop Yield Prediction Using Neural Network Techniques. J. Remote Sens. 2010, 2, 673-696. [CrossRef]

16. Allbed, A.; Kumar, L.; Aldakheel, Y.Y. Assessing soil salinity using soil salinity and vegetation indices derived from IKONOS high-spatial resolution imageries: Applications in a date palm dominated region. Geoderma 2014, 230-231, 1-8. [CrossRef]

17. Veraverbeke, S.; Gitas, I.; Katagis, T.; Polychronaki, A.; Somers, B.; Goossens, R. Assessing post-fire vegetation recovery using red-near infrared vegetation indices: Accounting for background and vegetation variability. ISPRS J. Photogramm. Remote Sens. 2012, 68, 28-39. [CrossRef]

18. Zhang, X.Y.; Friedl, M.A.; Schaaf, C.B.; Strahler, A.H.; Hodges, J.C.F.; Gao, F.; Reed, B.C.; Huete, A. Monitoring vegetation phenology using MODIS. Remote Sens. Environ. 2003, 84, 471-475. [CrossRef]

19. Huete, A.; Didan, K.; Miura, T.; Rodriguez, E.P.; Gao, X.; Ferreira, L.G. Overview of the radiometric and biophysical performance of the MODIS vegetation indices. Remote Sens. Environ. 2002, 83, 195-213. [CrossRef]

20. Barrett, E.C.; Curtis, L.F. Introduction to environmental remote sensing. In Introduction to Environmental Remote Sensing, 3rd ed.; Barrett, E.C., Curtis, L.F., Eds.; Chapman \& Hall: London, UK, 1992.

21. Myneni, R.B.; Hoffman, S.; Knyazikhin, Y.; Privette, J.L.; Glassy, J.; Tian, Y.; Wang, Y.; Song, X.; Zhang, Y.; Smith, G.R.; et al. Global products of vegetation leaf area and fraction absorbed PAR from year one of MODIS data. Remote Sens. Environ. 2002, 83, 214-231. [CrossRef]

22. Cao, R.Y.; Shen, M.G.; Zhou, J.; Chen, J. Modeling vegetation green-up dates across the Tibetan Plateau by including both seasonal and daily temperature and precipitation. Agric. For. Meteorol. 2018, 249, 176-186. [CrossRef]

23. Zhang, X.; Tarpley, D.; Sullivan, J. Diverse responses of vegetation phenology to a warming climate. Geophys. Res. Lett. 2007, 34, 255-268. [CrossRef]

24. Friedl, M.A.; McIver, D.K.; Hodges, J.C.; Zhang, X.Y.; Muchoney, D.; Strahler, A.H.; Woodcock, C.E.; Gopal, S.; Schneider, A.; Cooper, A.; et al. Global land cover mapping from MODIS: Algorithms and early results. Remote Sens. Environ. 2002, 83, 287-302. [CrossRef]

25. Crow, W.T.; Kumar, S.V.; Bolten, J.D. On the utility of land surface models for agricultural drought monitoring. Hydrol. Earth Syst. Sci. 2012, 16, 3451-3460. [CrossRef] 
26. Huete, A. A soil-adjusted vegetation index (SAVI). Remote Sens. Environ. 1988, 17, 37-53. [CrossRef]

27. Gilbert, M.A.; Gonzalez-Piqueras, J.; Garcia-Haro, F.; Melia, J. A generalized soil-adjusted vegetation index. Remote Sens. Environ. 2002, 82, 303-310. [CrossRef]

28. Huete, A.; Justice, C.; Liu, H. Development of vegetation and soil indices for MODIS-EOS. Remote Sens. Environ. 1994, 49, 224-234. [CrossRef]

29. Baret, F.; Guyot, G. Potentials and limits of vegetation indices for LAI and APAR assessment. Remote Sens. Environ. 1991, 35, 161-173. [CrossRef]

30. Qi, J.; Chehbouni, A.; Huete, A.R.; Kerr, Y.H. Modified Soil Adjusted Vegetation Index (MSAVI). Remote Sens. Environ. 1994, 48, 119-126. [CrossRef]

31. Rondeaux, G.; Steven, M.; Baret, F. Optimization of soil-adjusted vegetation indices. Remote Sens. Environ. 1996, 55, 95-107. [CrossRef]

32. Liu, H.Q.; Huete, A. A feedback-based modification of the NDVI to minimize canopy background and atmospheric noise. IEEE Trans. Geosci. Remote Sens. 1995, 33, 457-465. [CrossRef]

33. Huete, A.; Justice, C. MODIS Vegetation Index (MOD 13) Algorithm Theoretical Basis Document. Am. J. Plant Sci. 1999, 7, 1-59.

34. Weng, Q. Thermal infrared remote sensing for urban climate and environmental studies: Methods, applications, and trends. Remote Sens. 2009, 64, 335-344. [CrossRef]

35. Stark, B.; Smith, B.; Chen, Y. Survey of thermal infrared remote sensing for Unmanned Aerial Systems. In International Conference on Unmanned Aircraft Systems (ICUAS); IEEE: Orlando, FL, USA, 2014; pp. 1294-1299.

36. Anderson, M.C.; Hain, C.; Otkin, J.; Zhan, X.; Mo, K.; Svoboda, M.; Wardlow, B.; Pimstein, A. An Intercomparison of Drought Indicators Based on Thermal Remote Sensing and NLDAS-2 Simulations with U.S. Drought Monitor Classifications. J. Hydrometeorol. 2013, 14, 1035-1056. [CrossRef]

37. Gago, J.; Douthe, C.; Coopman, R.E.; Gallego, P.P.; Ribas-Carbo, M.; Flexas, J.; Escalona, J.; Medrano, H. UAVs challenge to assess water stress for sustainable agriculture. Agric. Water Manag. 2015, 153, 9-19. [CrossRef]

38. Radoglou-Grammatikis, P.; Sarigiannidis, P.; Lagkas, T.; Moscholios, I. A compilation of UAV applications for precision agriculture. Comput. Netw. 2020, 72, 107148. [CrossRef]

39. Calderón, R.; Navas-Cortés, J.A.; Lucena, C.; Zarco-Tejada, P.J. High-resolution airborne hyperspectral and thermal imagery for early detection of Verticillium wilt of olive using fluorescence, temperature and narrow-band spectral indices. Remote Sens. Environ. 2013, 139, 231-245. [CrossRef]

40. Sagan, V.; Maimaitijiang, M.; Sidike, P.; Eblimit, K.; Peterson, K.; Hartling, S.; Esposito, F.; Khanal, K.; Newcomb, M.; Pauli, D.; et al. UAV-Based High Resolution Thermal Imaging for Vegetation Monitoring, and Plant Phenotyping Using ICI 8640 P, FLIR Vue Pro R 640, and thermoMap Cameras. Remote Sens. 2019, 11, 330. [CrossRef]

41. Ludovisi, R.; Tauro, F.; Salvati, R.; Khoury, S.; Mugnozza, G.S.; Harfouche, A. Uav-based thermal imaging for high-throughput field phenotyping of black poplar response to drought. Front. Plant Sci. 2017, 8, 1-18. [CrossRef]

42. Costa, J.M.; Grant, O.M.; Chaves, M.M. Thermography to explore plant-environment interactions. J. Exp. Bot. 2013, 64, 3937-3949. [CrossRef]

43. Ghulam, A.; Li, Z.L.; Qin, Q.; Yimit, H.; Wang, J. Estimating crop water stress with ETM+ NIR and SWIR data. Agric. For. Meteorol. 2008, 148, 1679-1695. [CrossRef]

44. Alves, I.; Pereira, L.S. Non-water-stressed baselines for irrigation scheduling with infrared thermometers: A new approach. Irrig. Sci. 2000, 19, 101-106. [CrossRef]

45. Jones, H.G.; Stoll, M.; Santos, T.; De Sousa, C.; Chaves, M.M.; Grant, O.M. Use of infrared thermography for monitoring stomatal closure in the field: Application to grapevine. J. Exp. Bot. 2002, 53, 2249-2260. [CrossRef] [PubMed]

46. Leinonen, I.; Jones, H.G. Combining thermal and visible imagery for estimating canopy temperature and identifying plant stress. J. Exp. Bot. 2004, 55, 1423-1431. [CrossRef] [PubMed]

47. Moran, M.S.; Clarke, T.R.; Inoue, Y.; Vidal, A. Estimating crop water deficit using the relation between surface-air temperature and spectral vegetation index. Remote Sens. Environ. 1994, 49, 246-263. [CrossRef]

48. Verhoelst, T.; Granville, J.; Hendrick, F.; Kohler, U.; Lerot, C.; Pommereau, J.P.; Redondas, A.; Van Roozendael, M.; Lambert, J.C. Metrology of ground-based satellite validation: Co-location mismatch and smoothing issues of total ozone comparisons. Atmos. Meas. Tech. 2015, 8, 5039-5062. [CrossRef] 
49. Rahman, H. Satellite based crop monitoring and estimation system for food security application in Bangladesh. In Expert Meeting on Crop Monitoring for Improved Food Security; Geography: Vientiane, Laos, 2014.

50. Zhang, J. Multisource remote sensing data fusion: Status and trends. Int. J. Image Data Fusion 2010, 1, 5-24. [CrossRef]

51. Dube, T.; Mutanga, O. Evaluating the utility of the medium-spatial resolution Landsat 8 multispectral sensor in quantifying aboveground biomass in uMgeni catchment, South Africa. ISPRS J. Photogramm. Remote Sens. 2015, 101, 36-46. [CrossRef]

52. Roy, D.P.; Qin, Y.; Kovalskyy, V.; Vermote, E.F.; Ju, J.; Egorov, A.; Hansen, M.C.; Kommareddy, I.; Yan, L. Conterminous United States demonstration and characterization of MODIS-based Landsat ETM + atmospheric correction. Remote Sens. Environ. 2014, 140, 433-449. [CrossRef]

53. Wulder, M.A.; Hilker, T.; White, J.C.; Coops, N.C.; Masek, J.G.; Pflugmacher, D.; Crevier, Y. Virtual constellations for global terrestrial monitoring. Remote Sens. Environ. 2015, 170, 62-76. [CrossRef]

54. Cantore, V.; Iovino, F.; Pontecorvo, G. Aspetti Climatici e Zone Fitoclimatiche Della Basilicata; CNR-IEIF: Cosenza, Italy, 1987; p. 49.

55. Cassi, F.; Viviano, L. Suoli della Basilicata-Carta pedologica della Regione Basilicata in scala 1:250.000. In Regione Basilicata-Dip. Agricoltura e Sviluppo Rurale. Direzione Generale; Reg. Basilicata-Dip. Agric. Svilup. Rurale. Dir. Gen.: Potenza, Italy, 2006.

56. Allen, R.G.; Pereira, L.S.; Raes, D.; Smith, M. Crop evapotranspiration. In FAO Irrigation and Drainage Paper 56; FAO: Rome, Italy, 1998; p. 300.

57. Todorovic, M. An Excel-based tool for real time irrigation management at field scale. In Proceedings of the International Symposium on Water and Land Management for Sustainable Irrigated Agriculture, Adana, Turkey, 4-8 April 2006.

58. Li, J.; Roy, D.P. A global analysis of Sentinel-2A, Sentinel-2B and Landsat-8 data revisit intervals and implications for terrestrial monitoring. Remote Sens. 2017, 9, 902.

59. Rouse, J.W.; Haas, R.H.; Schell, J.A.; Deering, D.; Deering, W. Monitoring vegetation systems in the Great Plains with ERTS. In Proceedings of the ERTS Third Symposium, NASA SP-351, Washington, DC, USA, 10-14 December 1973; pp. 309-317.

60. Boegh, E.; Soegaard, H.; Thomsen, A. Evaluating evapotranspiration rates and surface conditions usig Landsat TM to estimate atmospheric resistance and surface resistance. Remote Sens. Environ. 2002, 79, 329-343. [CrossRef]

61. Jimenez-Munoz, J.C.; Sobrino, J.A. Split-Window Coefficients for Land Surface Temperature Retrieval from Low-Resolution Thermal Infrared Sensors. IEEE Geosci. Remote Sens. Lett. 2008, 5, 806-809. [CrossRef]

62. Skokovic, D.; Sobrino, J.A.; Jimenez-Munoz, J.C.; Soria, G.; Julien, Y.; Mattar, C.; Jordi, C. Calibration and Validation of Land Surface Temperature for Landsat 8-TIRS Sensor. Land Prod. Valid. Evol. 2014, 27, 6-9.

63. Sobrino, J.A.; Soria, G.; Prata, A.J. Surface temperature retrieval from Along Track Scanning Radiometer 2 data: Algorithms and validation. J. Geophys. Res. 2004, 109. [CrossRef]

64. Sobrino, J.A.; Jimenez-Muoz, J.C.; Soria, G.; Romaguera, M.; Guanter, L.; Moreno, J.; Plaza, A.; Martinez, P. Land surface emissivity retrieval from different VNIR and TIR sensors. IEEE Geosci. Remote Sens. Trans. 2008, 46, 316-327. [CrossRef]

65. Wang, K.C.; Wan, Z.M.; Wang, P.C.; Sparrow, M.; Liu, J.M.; Zhou, X.J.; Haginoya, S. Estimation of Surface Long-Wave Radiation and Broadband Emissivity Using Moderate Resolution Imaging Spectroradiometer (MODIS) Land Surface Temperature/Emissivity Products. J. Geophys. Res. 2005, 110. [CrossRef]

66. Carlson, T.N.; Ripley, D.A. On the Relation between NDVI, Fractional Vegetation Cover, and Leaf Area Index. Remote Sens. Environ. 1997, 62, 241-252. [CrossRef]

67. Sobrino, J.A.; Raissouni, N. Toward Remote Sensing Methods for Land Cover Dynamic Monitoring: Application to Morocco. Int. J. Remote Sens. 2000, 21, 353-366. [CrossRef]

68. Sobrino, J.A.; Jimenez-Munoz, J.C.; Paolini, L. Land surface temperature retrivel from LANDSAT TM5. Remote Sens. Environ. 2004, 90, 434-440. [CrossRef]

69. Baldridge, A.; Hook, S.; Grove, C.; Rivera, G. The ASTER spectral library version 2.0. Remote Sens. Environ. 2009, 113, 711-715. [CrossRef]

70. Pingbin, J.; Quan, W.; Atsuhiro, I.; John, T. Retrieval of seasonal variation in photosynthetic capacity from multi-source vegetation indices. Ecol. Inform. 2012, 7, 7-18. 
71. Petar, D.; Ilina, K.; Eugenia, R.; Lachezar, F.; Iliana, I.; Georgi, J.; Alexander, G.; Martin, B.; Veneta, K.; Viktor, K.; et al. Estimation of biophysical and biochemical variables of winter wheat through Sentinel-2 vegetation indices. Bulg. J. Agric. Sci. 2019, 25, 819-832.

72. Edward, P.G.; Alfredo, R.H.; Pamela, L.N.; Stephen, G.N. Relationship Between Remotely-sensed Vegetation Indices, Canopy Attributes and Plant Physiological Processes: What Vegetation Indices Can and Cannot Tell Us about the Landscape. Sensors 2008, 8, 2136-2160.

73. Daniel, M.; Francesco, P.; Martina, T.; Rossella, N.; Alfredo, A.; Andrea, N. Correlation of Field-Measured and Remotely Sensed Plant Water Status as a Tool to Monitor the Risk of Drought-Induced Forest Decline. Forests 2020, 11, 77.

74. Tanriverdi, C. Available Water Effects on Water Stress Indices for Irrigated Corn Grown in Sandy Soils. Ph.D. Thesis, Department of Chemical and Bioresource Engineering, Colorado State University, Fort Collins, CO, USA, 2010.

75. Hu, X.; Shi, L.; Lin, L.; Zhang, B.; Zha, Y. Optical-based and thermal-based surface conductance and actual evapotranspiration estimation, an evaluation study in the North China Plain. Agric. For. Meteorol. 2018, 263, 449-464. [CrossRef]

76. Zhang, R.H. Quantitative Model of Thermal Infrared Remote Sensing and Ground-Based Experiments; Science Press: Beijing, China, 2009.

77. Yang, Y.; Shang, S.; Guan, H.; Jiang, L. A novel algorithm to assess gross primary production for terrestrial ecosystems from MODIS imagery. J. Geophys. Res. 2013, 118, 2284-2300. [CrossRef]

78. Fensholt, R.; Sandholt, I.; Rasmussen, M.S. Evaluation of MODIS LAI, fAPAR and the relation between fAPAR and NDVI in a semi-arid environment using in situ measurements. Remote Sens. Environ. 2004, 91, 490-507. [CrossRef]

79. Fu, Y.; Yang, G.; Wang, J.; Song, X.; Feng, H. Winter wheat biomass estimation based on spectral indices, band depth analysis and partial least squares regression using hyperspectral measurements. Comput. Electron. Agric. 2014, 100, 51-59. [CrossRef]

80. Yue, J.; Yang, G.; Li, C.; Li, Z.; Wang, Y.; Feng, H.; Xu, B. Estimation of Winter Wheat Above-Ground Biomass Using Unmanned Aerial Vehicle-Based Snapshot Hyperspectral Sensor and Crop Height Improved Models. Remote Sens. 2017, 9, 708. [CrossRef]

81. Cho, M.A.; Skidmore, A.; Corsi, F.; Van Wieren, S.E.; Sobhan, I. Estimation of green grass/herb biomass from airborne hyperspectral imagery using spectral indices and partial least squares regression. Int. J. Appl. Earth Obs. Geoinf. 2007, 9, 414-424. [CrossRef]

82. Humbeck, K.; Quast, S.; Krupinska, K. Functional and molecular changes in the photosynthetic apparatus during senescence of flag leaves from field-grown barley plants. Plant Cell Environ. 1996, 19, 337-344. [CrossRef]

83. Sun, H.; Li, M.Z.; Zhao, Y.; Zhang, Y.E.; Wang, X.M.; Li, X.H. The Spectral Characteristics and Chlorophyll Content at Winter Wheat Growth Stages. Spectrosc. Spectr. Anal. 2010, 30, 192-196.

84. Stamatiadis, S.; Taskos, D.; Tsadilas, C.; Christofides, C.; Tsadila, E.; Schepers, J.S. Relation of ground-sensor canopy reflectance to biomass production and grape color in two merlot vineyards. Am. J. Enol. Vitic. 2006, 57, 415-422.

85. Yue, J.; Feng, H.; Jin, X.; Yuan, H.; Zhou, C.; Yang, G.; Tian, Q. A Comparison of Crop Parameters Estimation Using Images from UAV-Mounted Snapshot Hyperspectral Sensor and High-Definition Digital Camera. Remote Sens. 2018, 10, 1138. [CrossRef]

86. Biudes, M.S.; Machado, N.G.; Danelichen, V.H.M.; Souza, M.C.; Vourlitis, G.L.; Nogueira, J.S. Ground and remote sensing-based measurements of leaf area index in a transitional forest and seasonal flooded forest in Brazil. Int. J. Biometeorol. 2014, 58, 1181-1193. [CrossRef]

87. Demetriades-Shah, T.H.; Kanemasu, E.T.; Flitcroft, I.D.; Su, H. Comparison of ground- and satellite-based measurements of the fraction of photosynthetically active radiation intercepted by tallgrass prairie. J. Geophys. Res. Atmos. 1992, 97, 18947-18950. [CrossRef]

88. Tittebrand, A.; Spank, U. Comparison of satellite and ground-based NDVI above different land-use types. Theor. Appl. Climatol. 2009, 98, 171-186. [CrossRef]

89. Wittamperuma, I.; Hafeez, M.; Pakparvar, M.; Louis, J. Remote-sensing-based biophysical models for estimating LAI of irrigated crops in Murry darling basin. Int. Arch. Photogramm. Remote Sens. Spat. Inf. Sci. 2012, 34, 367-373. [CrossRef]

90. Jackson, R.D. Canopy temperature and crop water stress. Adv. Irrig. 1982, 1, 43-45. 
91. Mendez-Barroso, L.A.; Garatuza-Payan, J.; Vivoni, E.R. Quantifying water stress on wheat using remote sensing in the Yaqui Valley, Sonora, Mexico. Agric. Water Manag. 2008, 95, 725-736. [CrossRef]

92. Reynolds, B.C.; Hunter, M.D. Responses of soil respiration, soil nutrients, and litter decomposition to inputs from canopy herbivores. Soil Biol. Biochem. 2001, 33, 1641-1652. [CrossRef]

(C) 2020 by the authors. Licensee MDPI, Basel, Switzerland. This article is an open access article distributed under the terms and conditions of the Creative Commons Attribution (CC BY) license (http://creativecommons.org/licenses/by/4.0/). 